\title{
A Chemotype That Inhibits Three Unrelated Pathogenic Targets: The Botulinum Neurotoxin Serotype A Light Chain, P. falciparum Malaria, and the Ebola Filovirus
}

Igor Opsenica, ${ }^{\dagger}$ James C. Burnett, ${ }^{*, \neq}$ Rick Gussio, ${ }^{\S}$ Dejan Opsenica," Nina Todorović," Charlotte A. Lanteri, ${ }^{\perp}$ Richard J. Sciotti, ${ }^{\perp}$ Montip Gettayacamin, ${ }^{\#}$ Nicoletta Basilico, ${ }^{\nabla}$ Donatella Taramelli, ${ }^{\nabla}$ Jonathan E. Nuss, ${ }^{\circ}$ Laura Wanner, ${ }^{\bigcirc}$ Rekha G. Panchal, ${ }^{\bigcirc}$ Bogdan A. Šolaja, ${ }^{*+}$ and Sina Bavari*, ${ }^{*}$

${ }^{\dagger}$ Faculty of Chemistry, University of Belgrade, Studentski trg 16, P.O. Box 51, 11158, Belgrade, Serbia

${ }^{\ddagger}$ Target Structure-Based Drug Discovery Group, SAIC-Frederick, Inc., National Cancer Institute at Frederick, P.O. Box B, Frederick, Maryland 21702, United States

${ }^{\S}$ Developmental Therapeutics Program, National Cancer Institute at Frederick, P.O. Box B, FVC 310, Frederick, Maryland 21702, United States

"Institute of Chemistry, Technology, and Metallurgy, Belgrade, Serbia

${ }^{\perp}$ Division of Experimental Therapeutics, Walter Reed Army Institute of Research, Silver Spring, Maryland 20910, United States

${ }^{\#}$ United States Army Medical Component, Armed Forces Research Institute of Medical Science, Department of Veterinary Medicine, Bangkok, Thailand

${ }^{\nabla}$ Dipartimento di Sanità Pubblica-Microbiologia-Virologia, Università di Milano, Via Pascal 36, 20133 Milano, Italy

OUnited States Army Medical Research Institute of Infectious Diseases, Fort Detrick, 1425 Porter Street, Frederick, Maryland 21702, United States

Supporting Information

ABSTRACT: A 1,7-bis(alkylamino)diazachrysene-based small molecule was previously identified as an inhibitor of the botulinum neurotoxin serotype A light chain metalloprotease. Subsequently, a variety of derivatives of this chemotype were synthesized to develop structure-activity relationships, and all are inhibitors of the BoNT/A LC. Three-dimensional analyses indicated that half of the originally discovered 1,7-DAAC

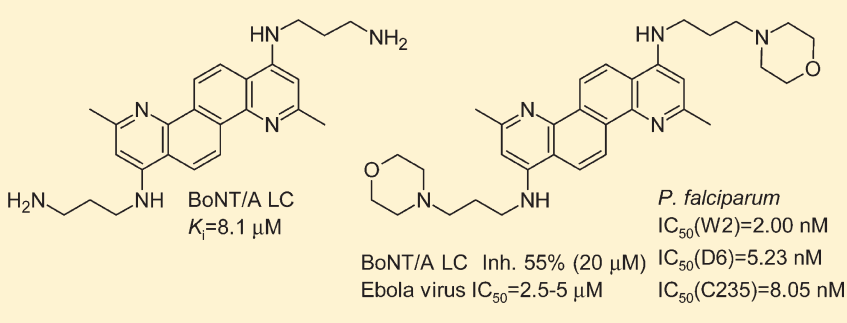
structure superimposed well with 4-amino-7-chloroquinoline-

Ebola virus $\mathrm{IC}_{50}=2.5-5 \mu \mathrm{M} \quad \mathrm{IC}_{50}(\mathrm{C} 235)=8.05 \mathrm{nM}$ based antimalarial agents. This observation led to the discovery that several of the 1,7-DAAC derivatives are potent in vitro inhibitors of Plasmodium falciparum and, in general, are more efficacious against CQ-resistant strains than against CQ-susceptible strains. In addition, by inhibiting $\beta$-hematin formation, the most efficacious 1,7-DAAC-based antimalarials employ a mechanism of action analogous to that of 4,7-ACQ-based antimalarials and are well tolerated by normal cells. One candidate was also effective when administered orally in a rodent-based malaria model. Finally, the 1,7-DAAC-based derivatives were examined for Ebola filovirus inhibition in an assay employing Vero76 cells, and three provided promising antiviral activities and acceptably low toxicities.

\section{INTRODUCTION}

The present manuscript describes a series of 1,7-bis(aminoalkyl)diazachrysene (1,7-DAAC)-based derivatives that inhibit three different pathogenic targets: the botulinum neurotoxin serotype A light chain (BoNT/A LC) (a Zn(II) metalloprotease that is responsible for the paralysis associated with botulism), Plasmodium falciparum (which causes malaria), and the Ebola filovirus (which causes hemorrhagic fever). The three targets are described below.

Botulinum neurotoxins (BoNTs), secreted by anaerobic, spore-forming bacterium Clostridium botulinum, are the most potent of bacterial toxins. ${ }^{1}$ Due to their ease of dissemination ${ }^{2}$ and lethality, ${ }^{3}$ BoNTs are classified as category A, highest priority biothreat agents by the Centers for Disease Control and Prevention $(\mathrm{CDC}){ }^{4}$

There are seven known BoNT serotypes (designated A-G). ${ }^{3}$ All are composed of a heavy chain (HC) component and a light chain (LC) component. ${ }^{5}$ The LC is a $\mathrm{Zn}$ (II) metalloprotease. The HC mediates translocation into the neuronal cytosol. After cell internalization, the LC is liberated from the $\mathrm{HC}$, and depending on the serotype, cleaves one of three proteins

Received: July 24, 2010

Published: January 25, 2011 
composing the soluble $\mathrm{N}$-ethylmaleimide-sensitive fusion protein attachment protein receptor (SNARE) complex. ${ }^{3}$ The proteolysis of SNARE proteins prevents the release of acetylcholine filled vesicles into neuromuscular junctions, resulting in the flaccid paralysis associated with botulism. ${ }^{3,5}$

Currently, the only treatment for BoNT poisoning is the administration of antitoxin vaccine. ${ }^{3,6}$ However, the vaccine cannot inhibit the toxin once it penetrates into the neuronal cytosol, and the only subsequent life-saving option available is clinically expensive, longer-term mechanical ventilation. ${ }^{2 b, 6}$ Consequently, due to the currently limited options for treating BoNT poisoning, there is a significant interest in the development of a $\operatorname{drug}(\mathrm{s})$ that will rescue neurons postintoxication, with the vast majority of research to date focusing on the BoNT/A LC. ${ }^{3,7}$ This serotype LC cleaves SNARE component synaptosomal associated protein of $25 \mathrm{kDa}(\mathrm{SNAP}-25)^{8}$ and is the longest acting of the LC serotypes in the neuronal cytosol. ${ }^{9}$

Malaria is a devastating disease resulting from mosquitovectored infection by protozoan parasites of the genus Plasmodium, with $P$. falciparum being the predominant species in subSaharan Africa. ${ }^{10}$ It is estimated that $300-500$ million people contract malaria annually, with over 1 million deaths occurring mostly in young children and pregnant women. ${ }^{11}$ Aggravating the problems associated with this illness has been/is the development of widespread drug-resistance to chloroquine (CQ), which was the standard antimalarial drug for many years, ${ }^{10}$ as well as the very recently reported, reduced clinical efficacy of drug combinations containing artemisinin, mostly in SE Asia. ${ }^{12}$

During the complex lifecycle of $P$. falciparum, ${ }^{10}$ there is a debilitating, cyclical blood stage during which the protozoan infests red blood cells ( $\mathrm{RBC})$, digests hemoglobin $(\mathrm{Hb})$ within its food vacuole (FV) (via proteolysis), replicates, and ruptures the RBC. This event leads to the release of new merozoites that continue the intraerythrocytic infestation cycle.

The biodegradation products of $\mathrm{FV}$ mediated $\mathrm{Hb}$ consumption primarily include: (1) insoluble hemozoin crystals (resulting from $\mathrm{Hb}$ heme detoxification) and (2) individual amino acids (resulting from $\mathrm{Hb}$ globin digestion). Commonly used antimalarial drugs are thought to kill the parasite either by producing toxic free radicals (for the latest results in the field, see refs 10,13) or by blocking the formation of $\beta$-hematin. This latter mechanism appears to be employed by 4-amino-7-chloroquinoline (4,7ACQ)-based antimalarial drugs, and results in the inhibition of heme detoxification, i.e., the consequent increase in the concentration of toxic heme within the FV causes parasite death. ${ }^{10,14}$ However, it should be noted that the heme detoxification pathway is not directly involved in CQ resistance. Instead, resistance is conferred by drug transporter (PfCRT, Pgh1, and PfMRP) mutations that alter drug accumulation in the parasite by either reducing drug uptake, or increasing drug efflux, or both. ${ }^{15}$ In addition, it is important to note that a very recent study indicates that reduced CQ accumulation is not the underlying cause of CQ resistance. ${ }^{16}$ Hence, there is no direct correlation between in vitro antimalarial activity and heme binding and/or inhibition of hemozoin formation. Therefore, other parameters such as lipophilicity and $\mathrm{pH}$-driven drug accumulation in the parasite's FV must play an important role in antimalarial activity. ${ }^{14 \mathrm{~b}}$ Given these discoveries, significant focus has been placed on the synthesis and development of novel 4,7-ACQ-based molecules that inhibit hemozoin formation ${ }^{17}$ and on the screening of compound libraries to detect novel chemotypes with similar antimalarial mechanisms. ${ }^{18}$ Compounds that are currently of significant interest include hematin binding 4,7-ACQ-hybrid drug reversals, ${ }^{19}$ acridones, ${ }^{20}$ 4,7-ACQ-astemizole- ${ }^{21}$ and 4,7ACQ-chlotrimazol-derived hybrids, ${ }^{22}$ and new 4,7-ACQ and acridine derivatives. ${ }^{23}$

The Ebola filovirus (EBOV) is a member of the Family Filoviridae (Order Mononegavirales). ${ }^{24}$ Genetically, EBOV is a nonsegmented, single-stranded negative sense RNA virus that is endemic to sub-Saharan Africa, and sporadic outbreaks of naturally occurring EBOV Zaire (Zaire virus) have been reported to cause severe hemorrhagic fever with a lethality rate approaching $90 \%{ }^{25}$

Major concerns regarding this virus include its potential global spread (due to increasing international travel) and its possible use as a biological weapon. ${ }^{4}$ Therefore, like BoNTs, this pathogen is listed as a CDC Category A biothreat agent, ${ }^{4}$ as there are no approved therapeutic options available for the prophylaxis and/or treatment of infected individuals. Currently, the only medical response to an "outbreak" relies on systematic case identification and contact tracing strategies, and the immediate isolation of suspect cases in specialized isolation wards. ${ }^{24,26}$ Therefore, a vaccine(s), as well as new antifilovirus drugs, are needed to counter this pathogen; however, a review of the literature afforded only a handful of small molecules that act as EBOV inhibitors. ${ }^{27}$

Herein, we provide results indicating that derivatives of a single chemotype (i.e., 1,7-DAAC-based small molecules) possess the ability to inhibit the three unrelated pathogens (described above): a bacterial toxin (the BoNT/A LC), a protozoan (malaria), and a filovirus (EBOV).

With respect to the importance of discovering small molecules that employ different mechanisms of action to treat more than one target/pathogen, this paradigm is a cost-effective means for treating diseases in general and especially those affecting (or that would affect) small populations as well as populations in third world countries (e.g., malaria). ${ }^{28}$ One example of such a small molecule is miltefosine, which was originally developed to treat breast cancer but was later found to be an effective treatment for visceral leishmaniasis (a sand-fly transmitted parasite disease estimated to kill 500000 people a year). ${ }^{29}$ A second example is Adefovir dipivoxil. This drug is used to treat chronic hepatitis B virus infection but was subsequently identified as a competitive inhibitor of anthrax edema factor (a key virulence factor in anthrax pathogenesis). ${ }^{30}$

\section{RESULTS AND DISCUSSION}

To initially discover novel small molecule (nonpeptidic) inhibitors (SMNPIs) of the BoNT/A LC, high-throughput screens of small molecule libraries were conducted and "hits" from the screens were verified using a previously reported HPLC-based assay. ${ }^{31}$ The chemical diversity of the initially discovered SMNPIs ranged from the rigid natural product Michellamine B to flexible bis-(4,7-ACQ) antimalarial agents. ${ }^{31}$ Following the three-dimensional (3-D) superimpositions of shared SMNPI chemical and steric features led to the generation of a common pharmacophore for BoNT/A LC inhibition. ${ }^{31}$ In subsequent studies, the pharmacophore provided the basis for developing 3-D search queries that were used to database mine more potent SMNPIs. ${ }^{32}$ Interestingly, two new SMNPI chemotypes that were discovered included 4,7-ACQ-cholic acid hybrids $^{33}$ and 4,7-ACQ-adamantane hybrids. ${ }^{34}$ Additionally, a 1,7-DAAC-based SMNPI, 1 (Scheme 1), was also database 
Scheme $1^{a}$

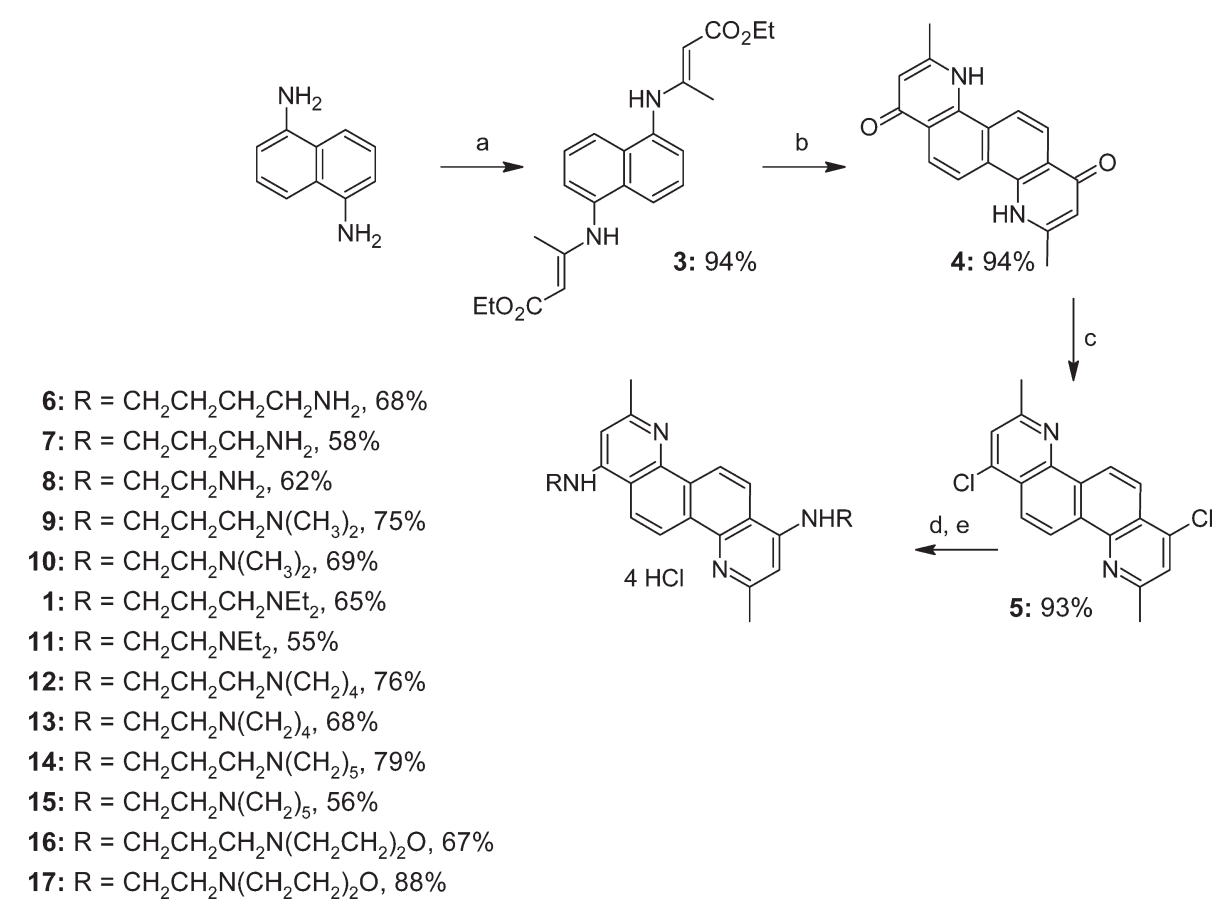

${ }^{a}$ (a) Ethyl acetoacetate, TsOH/EtOH, $\Delta$; (b) $\mathrm{MeSO}_{3} \mathrm{H} / \mathrm{P}_{2} \mathrm{O}_{5}, 90{ }^{\circ} \mathrm{C}$; (c) $\mathrm{POCl}_{3}, 90{ }^{\circ} \mathrm{C}$; (d) $\mathrm{RNH}_{2}, \mathrm{Ar}, \Delta$; (e) $\mathrm{HCl} / \mathrm{EtOH}, \mathrm{rt}$.

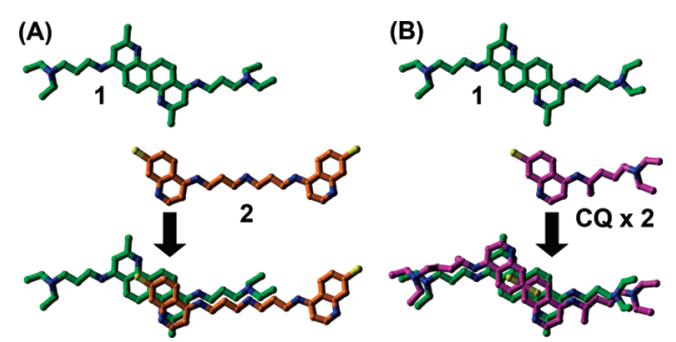

Figure 1. Compound 1 and antimalarial agents (that are also SMNPIs of the BoNT/A LC) superimpose well. (A) half of the structure of 1 superimposes with good chemical and steric complementarity with half of previously identified antimalarial agent/BoNT/A LC inhibitor 2. Carbon atoms are green for $\mathbf{1}$ and orange for $\mathbf{2}$. Nitrogen atoms are blue and chlorine atoms are yellow. (B) Two CQ (chloroquine) molecules superimposed with 1. CQ carbons are magenta. All other atom colors are as indicated for (A).

mined from the NCI Open Repository. ${ }^{35}$ Following 1 was used to unite different SMNPI chemotypes in a refined 3-Zone pharmacophore. ${ }^{35}$ Of significance to the research reported herein, 3-D superimpositions of the SMNPIs used to develop the refined 3-zone pharmacophore model indicated that $\mathbf{1}$ and previously identified SMNPI $2^{35}$ (which is also an antimalarial agent ${ }^{31}$ ) partially superimposed with remarkably good chemical and steric complementarity (Figure 1A). Not surprisingly, when 1 was superimposed with antimalarial drug CQ which was also previously found to weakly inhibit the BoNT/A LC, ${ }^{31,35}$ the same complementary chemical and steric convergence was observed. This structural convergence is even more pronounced when $\mathbf{1}$ and two condensed CQ molecules are superimposed (Figure 1B). This observation led to the hypothesis that $\mathbf{1}$ and its derivatives might possess antimalarial activity, and initial in vitro screening against P. falciparum revealed that these compounds are active against the parasite. Additional toxicity and pharmacokinetics profiling, followed by the in vivo testing of one of the most potent of the derivatives, also demonstrated significant potential for developing 1,7-DAAC-based SMNPIs as antimalarial therapeutics (vide infra).

Finally, it was previously discovered that 9 (Scheme 1) possesses anti-EBOV efficacy in vivo with no toxicity. ${ }^{27 a}$ Consequently, all of our 1,7-DAAC derivatives were examined for antiEBOV activities in a cell-based assay, and it was discovered that three of the derivatives afford good cellular protection, with very low toxicities, when dosed at $20 \mu \mathrm{M}$ concentrations. Hence, our results indicate that 1,7-DAAC-based derivatives represent new leads for therapeutic development against three different pathogenic targets.

The Synthesis of DAAC-Based Derivatives. Prior to the discovery that 1,7-DAAC-based SMNPI 1 was also active against $P$. falciparum strains as well as the EBOV filovirus, derivatives were synthesized to provide SAR for the development of this chemotype as a potential therapeutic to counter BoNT/A poisoning. Specifically, 1,7-DAAC derivatives exploring the bis(alkylamino) side-chains of 1 were generated (Scheme 1). In Scheme 1, a brief synopsis of the synthetic method used to obtain the derivatives is displayed (see the Experimental Section for details). First, commercially available 1,5-diaminonaphthalene was used to prepare intermediate 4 via the Conrad-Limpah reaction. Following, 4 was reacted with $\mathrm{POCl}_{3}$ to give dichloride 5 in $82 \%$ yield. Nucleophilic substitution with a variety of diamines, followed by $\mathrm{HCl}$ salt formation, provided $\mathbf{1}$ and derivatives 6-17 (overall yields ranged from $45 \%$ to $72 \%$ ).

Inhibition of the BoNT/A LC. Table 1 displays the inhibitory efficacies of 1 and 6-17 when examined in vitro at $20 \mu \mathrm{M}$ concentrations employing a well established HPLC-based assay for BoNT/A LC inhibition. ${ }^{36}$ Note, as indicated above, the 1,7DAAC derivatives were generated to determine the effects of 
Table 1. BoNT/A LC Inhibition and Antimalarial Activities for 1,7-DAAC Derivatives 1 and 6- 17

\begin{tabular}{|c|c|c|c|c|c|}
\hline \multirow[b]{2}{*}{ compd } & \multirow[b]{2}{*}{ BoNT/A LC \% inhibition $(\mu \mathrm{M})^{a}$} & \multicolumn{3}{|c|}{ antimalarial activity $\mathrm{IC}_{50}\left(\mathrm{IC}_{90}\right), \mathrm{nM}$} & \multirow[b]{2}{*}{$\mathrm{RI}^{e}$} \\
\hline & & D $6^{b}$ & $\mathrm{~W} 2^{c}$ & $\mathrm{C} 235^{d}$ & \\
\hline 6 & $72.32( \pm 4.6)$ & & & & \\
\hline 7 & $70.0( \pm 1.5)$ & $708.29(1011.31)$ & $1701.59(3262.40)$ & $2030.86(3049.06)$ & $2.40 / 2.87$ \\
\hline 8 & $62.7( \pm 2.0)$ & $270.29(355.08)$ & $871.25(1785.20)$ & $1021.04(1761.50)$ & $3.22 / 3.78$ \\
\hline 9 & $68.9( \pm 0.3)$ & $103.47(210.18)$ & $352.71(708.66)$ & $54.82(698.68)$ & $3.41 / 0.53$ \\
\hline 10 & $57.0( \pm 2.2)$ & $15.61(20.82)$ & 9.19 (31.23) & $15.27(26.02)$ & $0.59 / 0.98$ \\
\hline 1 & $64.7( \pm 1.8)$ & $30.01(49.53)$ & $8.65(46.73)$ & $66.50(285.70)$ & $0.29 / 2.22$ \\
\hline 11 & $55.4( \pm 0.6)$ & $6.01(9.01)$ & $3.48(10.12)$ & $3.32(3.79)$ & $0.57 / 0.55$ \\
\hline 12 & $73.5( \pm 0.2)$ & $14.84(39.41)$ & $7.75(25.37)$ & $34.29(95.17)$ & $0.52 / 2.31$ \\
\hline 13 & $60.3( \pm 1.8)$ & $16.76(32.28)$ & $8.11(28.00)$ & $25.90(40.28)$ & $0.48 / 1.54$ \\
\hline 14 & $66.1( \pm 2.9)$ & $9.26(17.43)$ & $6.98(22.50)$ & $24.84(41.22)$ & $0.75 / 2.68$ \\
\hline 15 & $63.4( \pm 3.9)$ & $8.79(13.21)$ & $5.50(15.37)$ & $10.55(14.93)$ & $0.62 / 1.20$ \\
\hline 16 & $55.6( \pm 0.1)$ & $5.23(8.47)$ & $2.00(6.38)$ & $8.05(17.36)$ & $0.38 / 1.54$ \\
\hline 17 & $39.0( \pm 2.0)$ & $5.93(12.60)$ & $6.12(11.50)$ & $9.84(16.48)$ & $1.03 / 1.66$ \\
\hline $\mathrm{CQ}^{f}$ & & $12.27(16.11)$ & $456.20(697.97)$ & $138.82(373.25)$ & $38.18 / 11.31$ \\
\hline $\mathrm{MFQ}^{f}$ & & $15.70(39.09)$ & $4.93(15.25)$ & $36.50(134.07)$ & $0.31 / 2.32$ \\
\hline $\mathrm{ART}^{g}$ & & $9.00(12.80)$ & $6.70(11.50)$ & $13.04(17.40)$ & $0.74 / 1.45$ \\
\hline
\end{tabular}

${ }^{a} \%$ inhibition calculated at $20 \mu \mathrm{M}$ conc. ${ }^{b}$ P. falciparum African D6 clone. ${ }^{c}$ P. falciparum Indochina W2 clone. ${ }^{d}$ P. falciparum multidrug resistant C235 strain (Thailand). ${ }^{e}$ The resistance index (RI) is defined as the ratio of the $\mathrm{IC}_{50}$ for the resistant versus sensitive strain, W2/D6 and C235/D6, respectively. ${ }^{f}$ Control drug (the average of seven replicates). ${ }^{g}$ The average of greater than eight replicates.

modifying the bis(alkylamino) side-chains (i.e., the symmetrical moieties extending from diazachrysene core (Scheme 1)) on BoNT/A LC inhibitory efficacy. Overall, the SAR indicates that propylamino linkers, as well as a butylamino linker, provide slightly increased inhibitory efficacies versus corresponding derivatives possessing ethyl linkers (Table 1). Specifically, 6 and $7,9,1,12,14$, and 16 are all consistently more potent than corresponding derivatives $8,10,11,13,15$, and 17 , respectively (Table 1).

By contrast, different substitutions on the side chain terminal nitrogens did not demonstrate the same consistency with respect to BoNT/A LC inhibition. For example, primary amine derivatives 6 and 7 are slightly more potent than 9 and 1, which possess $\mathrm{N}, \mathrm{N}$-dimethyl and $\mathrm{N}, \mathrm{N}$-diethyl substituents, respectively, and 14 and 17 , which incorporate the side chain nitrogens in piperidine and morpholine rings, respectively. However, 12, which incorporates the side chain nitrogens in pyrrolidine rings is equipotent to 6 , and more potent than 7 and $\mathbf{1 4}$, as well as all other derivatives presented in Table 1 . These results are indicative of potential steric limitations for side chain amino substitutions within the confines of their binding sites. Finally, it is notable that the inhibition data indicates that incorporating terminal morpholine rings (16 and 17 in Table 1) has a more pronounced negative impact on inhibitory efficacy versus all other presented derivatives. This data appears to indicate that either an unfavorable hydrophobic-polar or polar-polar contact between one (or both) of the morpholine ring oxygens and an enzyme residue(s) is occurring in the BoNT/A LC binding site. In agreement with this hypothesis, inhibition data shows that 14, which possesses hydrophobic carbon atoms in the same positions as the oxygen atoms of the morpholine rings of $\mathbf{1 6}$, is a more potent SMNPI.

To determine the type of inhibition kinetics employed by 1,7DAAC-derived SMNPIs, $K_{\mathrm{i}}$ values were determined for derivative pair $\mathbf{7}$ and $\mathbf{8}$. The inhibition kinetics for $\mathbf{7}$ and $\mathbf{8}$ mirror their $\%$ inhibition data (Table 1), with the $K_{\mathrm{i}}$ values for these SMNPIs $=8.1 \mu \mathrm{M}( \pm 1.2 \mu \mathrm{M})$ and $8.7 \mu \mathrm{M}( \pm 0.9 \mu \mathrm{M})$, respectively.
These data indicate that $\mathbf{7}$ and $\mathbf{8}$ are among the most potent of non-Zn(II) chelating SMNPIs reported in the literature to date. Additionally, plots of BoNT/A LC inhibition, versus increasing concentrations of 7 and 8 , indicate that these SMNPIs are competitive inhibitors (see Supporting Information, Figure S1). Consequently, on the basis of the fact that only conservative modifications were made to the bis-alkylamino side-chains of 1 and 6-17, it follows that SMNPIs 1, 6, and 9-17 should also be competitive inhibitors.

Furthermore, on the basis of the SAR for 1 and 6-17 and the relatively close inhibitory ranges for the majority of the derivatives, additional syntheses are required to further explore the impact of more pronounced alkylamino side chain substitutions. ${ }^{37}$

Antimalarial Activity: The Inhibition of $P$. falciparum Strains. As shown in Figure 1, classical 4,7-ACQ-based antimalarial agents $\mathbf{2}$ and $\mathbf{C Q}$ superimpose well with $\mathbf{1}$ (Figure 1). These observations led to the hypothesis that 1,7-DAAC-based SMNPIs of the BoNT/A LC (Table 1) might inhibit P. falcipar$u m$ by employing the same, or a similar, mechanism of action as that postulated for 4,7-ACQ-based antimalarial agents (i.e., the inhibition of hemozoin formation).

Subsequently, 1 and 6-17 were screened in vitro ${ }^{38}$ against three P. falciparum strains: D6 (a clone from the Sierra I/UNC isolates that is susceptible to CQ (CQS) and pyrimethamine, but which has reduced susceptibility to mefloquine and halofantrine), W2 (a clone of the Indochina I isolate that is resistant to chloroquine (CQR) and pyrimethamine, but which is susceptible to mefloquine), and C235 (a multidrug-resistant strain derived from Thailand, MDR) (Table 1).

In general, our hypothesis was correct, as the majority of the 1,7-DAAC SMNPIs are very potent antimalarial agents, inhibiting the proliferation of all CQR, MDR, and CQS P. falciparum strains with low nanomolar range efficacies. SMNPIs 7 and 8, which possess side chains containing a primary amino group, are the least active of the derivatives (Table 1). By contrast, the inhibitory efficacies of the 1,7-DAAC derivatives gradually 
Table 2. $\boldsymbol{\beta}$-Hematin Inhibitory Assay for 1,7-DAAC Derivatives 13,16 , and $17^{a}$

$\begin{array}{cc}\text { compd } & \text { BHIA } \\ 13 & 0.401 \pm 0.09 \\ 16 & 0.520 \pm 0.12 \\ 17 & 0.473 \pm 0.04 \\ \text { CQ } & 1.09 \pm 0.10\end{array}$

${ }^{a} \mathrm{IC}_{50}$ values represent the molar equivalents of compound, relative to hemin, that inhibit $\beta$-hematin formation by $50 \%$. Data are the mean \pm $\mathrm{SD}$ of four replicates from two different experiments performed in duplicate.

improve with increasing substitution on the basic side chain nitrogens (compare 7 and $\mathbf{8}$ versus 1, and 9-11 (Table 1)). Moreover, the introduction of piperidine moieties $(14,15)$ further increases antimalarial activity, while the introduction of a heteroatom in the piperidine rings (to provide the morpholine substituents of 16 and 17) further enhanced activity against all examined P. falciparum strains (Table 1). Overall, out of 12 examined 1,7-DAAC derivatives, nine possess pronounced antimalarial activities (1, and 10-11), with the most potent antimalarial agents possessing diethyl (11), piperidine $(14,15)$, and morpholine substituents $(\mathbf{1 6}, \mathbf{1 7})$ (Table 1$)$. It is important to note that these low $\mathrm{IC}_{50}$ values are unusual for nonperoxide derived antimalarials: (1) nine derivatives with activities below $10 n M$ against CQR W2 strain and (2) $\mathbf{1}$ and 10-17 are generally more potent against $P$. falciparum $C Q R W 2$ strain than against $C Q S$ D6 strain $\left(\mathrm{RI}=0.29-0.75 ; \mathrm{RI}_{\mathrm{ART}}=0.74\right)$ (Table 1$)$. It should also be emphasized that 11,16 , and 17 are more potent than standard antimalarial drugs CQ MFQ and ART (Table 1). In particular, the ratios of increased inhibitory potencies indicate that these SMNPIs are: 1.5-2 times more potent against D6 than $\mathrm{CQ}, \mathrm{MFQ}$ and ART, respectively, 1.5-300 times more potent against $\mathrm{W} 2$ than $\mathrm{MFQ}, \mathrm{ART}$, and CQ, respectively, and 4-42 times more potent against C235 than ART, MFQ and $\mathrm{CQ}$ respectively (Table 1 ).

To obtain basic information about the antimalarial mechanism of action employed by the 1,7-DAAC-based SMNPIs shown in Table 1, derivatives $\mathbf{1 3}, \mathbf{1 6}$, and $\mathbf{1 7}$ were screened for suppression of $\beta$-hematin formation using a previously described $\beta$-hematin inhibitory activity assay (BHIA). ${ }^{39}$ Specifically, the assay monitors small molecule-based interference of the heme detoxification process employed by $P$. falciparum. In line with our hypothesis that 1,7-DAAC-based SMNPIs, like 4,7-ACQ-based antimalarials, would interfere with the heme detoxification mechanism, the results in Table 2 indicate that 13, 16, and 17 display dosedependent inhibition of $\beta$-hematin formation, with $\mathrm{IC}_{50}$ values that are considerably lower than that of $C Q$ thus demonstrating a significantly better ability to interact with hematin than CQ (as well as confirming our hypothesis). For information on dosedependent inhibition of $\beta$-hematin formation by the select SMNPIs, see Supporting Information, Figure S2.

Analysis of 1,7-DAAC Toxicity. Because the investigated SMNPIs are based on the 1,7-DAAC scaffold, close attention was paid to the possibility of toxicity issues. ${ }^{40}$ First, bis $(N, N$ diethyl)substituted derivative $\mathbf{1 1}$ and bismorpholino substituted derivatives 16 and 17 were chosen for advanced toxicity screening due to their potencies against the CQR W2 strain and the MDR C235 strain $\left(\mathrm{RI}_{11}=0.57 / 0.55, \mathrm{RI}_{16}=0.38 / 1.54, \mathrm{RI}_{17}=\right.$ $1.03 / 1.66$, respectively (Table 1$)$ ). In brief, SMNPI cytotoxicities were examined in a rat macrophage cell line, and low toxicities were observed for all three derivatives $\left(\mathrm{IC}_{50}\right.$ value range $=$ 7000-10000 nM, Table 3). Moreover, the potencies of these SMNPIs were further supported by corresponding $\mathrm{IC}_{90}$ values (Table 3), which are substantially higher than those of standard antimalarial drugs CQ, MFQ, and ART. ${ }^{41,42}$ Another important characteristic of 11, 16, and 17 is their lack of toxicity with respect to their high antimalarial activities against all three P. falciparum strains. In particular, all possess very high selectivity indices (SI $\geq$ 1000 (Table 3)).

No evidence of in vivo clinical toxicity was noted in P. berghei (P-line) malaria-infected mice (outbred ICR mice, Mus musculus) administered 11 at a dose of $160 \mathrm{mg} / \mathrm{kg}$ of body weight for 3 consecutive days by oral route, as evidenced by a lack of overt physical or behavioral changes in treated mice. Moreover, no signs of toxicity were observed as noted by twice daily observations of individual mouse behavior and appearance and by routine gross necropsy lesions indicating death due to fulminant malaria infection.

In addition, it is notable that $\mathbf{1 6}$ and $\mathbf{1 7}$ were examined against the National Cancer Institute's panel of 60 human tumor cell lines starting at concentrations of $10^{-4} \mathrm{M},{ }^{40}$ and their inhibitory activities were found to be very low, with mean growth percents of $92 \%$ and $91 \%$, respectively; hence, these data indicate that $\mathbf{1 6}$ and $\mathbf{1 7}$ are not toxic to a range of cancer cells.

In vitro metabolism studies were also performed with 11, 16, and $\mathbf{1 7}$ to assess their bioavailabilities upon oral administration. Metabolic stability assays were performed using mouse and human liver microsomes (MLM and HLM), respectively. ${ }^{43}$ Following, our results indicated that 11 and 17 were metabolically stable, with a half-lives $\left(t_{1 / 2}\right)>60 \mathrm{~min}$ in MLM and HLM, while bismorpholino derivative $\mathbf{1 6}$ was metabolically stable when exposed to MLM $\left(t_{1 / 2}>60 \mathrm{~min}\right)$ and appreciably stable when exposed to HLM: $t_{1 / 2}=40 \mathrm{~min}$ (Table 3). ${ }^{44}$

We presume that the low toxicities observed for the 1,7DAAC-based derivatives result from their $N$-substitutions at positions $C(1)$ and $C(7)$, as the side chains may suppress the metabolic activation and ultimate formation of DNA adducts. ${ }^{40}$ In this regard, toxicity issues need to be investigated in more detail; nevertheless, our initial results are encouraging, and prompted the in vivo testing of 11.

In Vivo Analysis of 11. On the basis of the favorable toxicity profiles indicated above, $\mathbf{1 1}$ was examined for antimalarial efficacy in a mouse model (groups of five mice were employed). A modified Thompson test model of malaria was used to determine the blood schizonticidal efficacy of 11. In this model, ICR mice are infected with $P$. berghei-infected red blood cells on day 0. SMNPI 11 was administered orally $(80 \mathrm{mg} / \mathrm{kg})$ on days 3, 4, and 5 after parasite inoculation (i.e., postestablishment of blood stage infection); the establishment of blood stage infection was confirmed by positive blood smear results for all mice on study day 3 (prior to SMNPI administration). SMNPI 11 cured one mouse out of five tested, as evidenced by a negative blood smear obtained on day 31 postinfection. In the other four mice in the test group, 11 provided blood stage suppressive activity, with the mice succumbing to infection between days 13 and 21 (postparasite inoculation). In contrast, control mice showed a high degree of parasitemia, succumbing to infection on days $7-8$ (postparasite inoculation).

The presumptive causal prophylactic activity ${ }^{50}$ of 11 was also investigated in an ICR mouse $P$. berghei (ANKA strain) sporozoite challenge model. Specifically, mice were inoculated with sporozoites on day 0 , and 11 was administered on days $-1,0$, and 
Table 3. Toxicity and Metabolic Stability of 1,7-DAAC Derivatives 11, 16, and $17^{a}$

\begin{tabular}{|c|c|c|c|c|c|c|c|c|}
\hline \multirow[b]{2}{*}{ compd } & \multirow{2}{*}{$\begin{array}{c}\text { toxicity against } \\
\text { RAW } 264.7 \\
\left(\mathrm{IC}_{50} ; \mathrm{IC}_{90}\right) \mathrm{nM}\end{array}$} & \multicolumn{3}{|c|}{$\begin{array}{l}\text { P.f. in vitro activity } \\
\left(\mathrm{IC}_{50} ; \mathrm{IC}_{90}\right) \mathrm{nM}\end{array}$} & \multicolumn{3}{|c|}{$\begin{array}{l}\text { selectivity index } \\
\left(\mathrm{IC}_{50} ; \mathrm{IC}_{90}\right)^{b}\end{array}$} & \multirow[b]{2}{*}{$\begin{array}{c}\text { metabolic stability } t_{1 / 2} \\
\text { (HLM; MLM, min) }\end{array}$} \\
\hline & & D6 & W2 & C235 & D6 & $\mathrm{W} 2$ & $\mathrm{C} 235$ & \\
\hline 11 & $9348 ; 10717$ & $6.01 ; 9.01$ & $3.48 ; 10.12$ & $3.32 ; 3.79$ & $1555.41 ; 1189.46$ & $2686.21 ; 1058.99$ & $281.66 ; 2827.70$ & $>60$; $>60$; no toxicity in vivo \\
\hline 16 & $7481 ; 11029$ & $5.23 ; 8.47$ & $2.00 ; 6.38$ & $8.05 ; 17.36$ & $1430.40 ; 1302.12$ & $3740.50 ; 1728.68$ & $929.32 ; 635.31$ & $40 ;>60$ \\
\hline 17 & $10174 ; 29916$ & $5.93 ; 12.60$ & $6.12 ; 11.50$ & $9.84 ; 16.48$ & $1715.68 ; 2374.36$ & $1662.42 ; 2601.48$ & $1033.94 ; 1815.35$ & $>60 ;>60$ \\
\hline
\end{tabular}

+1 (to investigate its prophylactic potential). On day 0, SMNPI 11 was dosed one hour prior to sporozoite inoculation. Results from these studies indicate that $\mathbf{1 1}$ does not provide prophylactic protection; however, 11 did delay parasite patency by 1 to 2 days, relative to control mice (all controls showed parasitemia on day 4), in three out of five mice that were orally dosed with $160 \mathrm{mg} / \mathrm{kg}$ for 3 days. Moreover, a lower prophylactic dose of 11 $(40 \mathrm{mg} / \mathrm{kg})$ resulted in a delayed patency of 1 day in one out of five mice. In both the Thompson blood stage and causal prophylaxis in vivo models, $\mathbf{1 1}$ was well tolerated and did not produce overt clinical manifestations of toxicity, as noted by twice daily observations of individual mouse behavior and appearance.

Routine necropsy was conducted on all mice treated with $\mathbf{1 1}$, and the results clearly showed that mice evaluated in both the Thompson blood stage and causal prophylaxis in in vivo models died as a result of parasitemia (and not from 11 related toxicity), as evidenced by pale and emaciated carcasses, the presence of dark-gray swollen gross lesions on the liver, and splenomegaly, all of which are indicative of malaria-induced death. The same signs of parasitemia-induced death were also observed during the necroscopy of control mice. Importantly, no toxicity was observed for mice treated with 11, as indicated by twice daily observations of individual mouse behavior and appearance and by routine gross necropsy lesions that are indicative of mouse death resulting from fulminant malaria infection.

The Analysis of 1,7-DAAC-Based Derivatives for AntiEBOV Activity. As indicated in the Introduction, it was previously discovered that 9 counters EBOV infection in vivo. ${ }^{27 a}$ Moreover, in the same publication, ${ }^{27 a}$ it was found that 9 is a broad-spectrum SMNPI that inhibits not only EBOV (a filovirus) but also other genetically distinct positive and negative-strand RNA viruses including: Rift Valley fever (a Bunyavirus), Dengue virus (a Flavivirus), hepatitis $\mathrm{C}$ virus (a Flavivirus), and HIV-1 (a retrovirus). Thus, it is hypothesized that the antiviral activity of 9, and other1,7-DAAC-based SMNPIs, results from the modulation of common cellular pathways involved in viral assembly and budding (which are utilized by a wide array of evolutionarily distant virus families). ${ }^{51}$ Recent findings ${ }^{27 a}$ prompted the examination of $\mathbf{1}$ and $6-\mathbf{1 7}$ for potential anti-EBOV activity. The results from testing the 1,7DAAC SMNPIs in a cell-based infection assay, using Vero76 (African green monkey kidney cells), indicated that the majority of the derivatives are toxic when administered at $20 \mu \mathrm{M}$ concentration. However, 11, 14, 16, and 17 were exceptions. These SMNPIs provided 97\%, 100\%, 96\%, and 53\% EBOV inhibition, respectively (Table 4). Following, dose-response studies conducted for 11,14 , and 16 indicated that these
Table 4. In Vitro Inhibition of EBOV by Select Derivatives $11,14,16$, and 17

\begin{tabular}{cccc} 
SMNPI & inhibition at $20 \mu \mathrm{M}(\%)$ & $\mathrm{IC}_{50}(\mu \mathrm{M})$ & toxicity at $20 \mu \mathrm{M}(\%)$ \\
11 & 97 & $5-10$ & $<20$ \\
14 & 100 & $\sim 5$ & $<20$ \\
16 & 96 & $2.5-5$ & $<20$ \\
17 & 53 & & \\
\hline
\end{tabular}

SMNPIs possess $\mathrm{IC}_{50}$ values in the $5 \mu \mathrm{M}$ range (Table 4 ), with cell toxicities of $<25 \%$ (Figure 2). Hence, these three 1,7-DAAC derivatives are among the most potent EBOV inhibitors discovered to date.

\section{CONCLUSION}

The identification of a 1,7-DAAC-based SMNPI as an inhibitor of the BoNT/A LC resulted in the syntheses of a variety of derivatives - all provided inhibition of the enzyme. Furthermore, the 3-D superimposition of originally identified 1,7-DAAC-based SMNPI 1 and the 4,7-ACQ components of classical antimalarial agents indicated good structural and chemical complementarity. This prompted investigations to determine if the 1,7-DAACbased derivatives described in this study might also inhibit P. falciparum (malaria). Additionally, a previous study indicated that 9 inhibits the Ebola filovirus; therefore all 1,7-DAAC derivatives were also examined against this pathogen. Hence, the results presented herein provide SAR for the 1,7-DAAC chemotype when examined against three different pathogenic targets: a bacterial toxin (the BoNT/A LC), a protozoan (P. falciparum malaria), and a filovirus (EBOV).

Results from these studies indicate that the presented 1,7DAAC-based SMNPIs inhibit the three unrelated pathogens by employing three different mechanisms of action, thus demonstrating the unique antipathogenic potential of this chemotype. Specifically: (1) BoNT/A LC metalloprotease inhibition is achieved via interaction with the enzyme's substrate binding cleft, (2) antimalarial efficacy appears to result from the suppression of $\beta$-hematin formation (see Tables 2), and 3 ) anti-EBOV efficacy most likely results from the modulation of a host cellular pathway (for example, a pathway facilitating viral assembly and budding). ${ }^{27,51}$

Interestingly, SAR for the inhibition of the three targets does not indicate a general correlation between 1,7-DAAC derivative side chain substitutions and related inhibitory potencies across pathogens. For example, primary amino substituents on the sidechains of the 1,7-DAAC core result in increased BoNT/A LC inhibitory potency while incorporating the side chain basic 


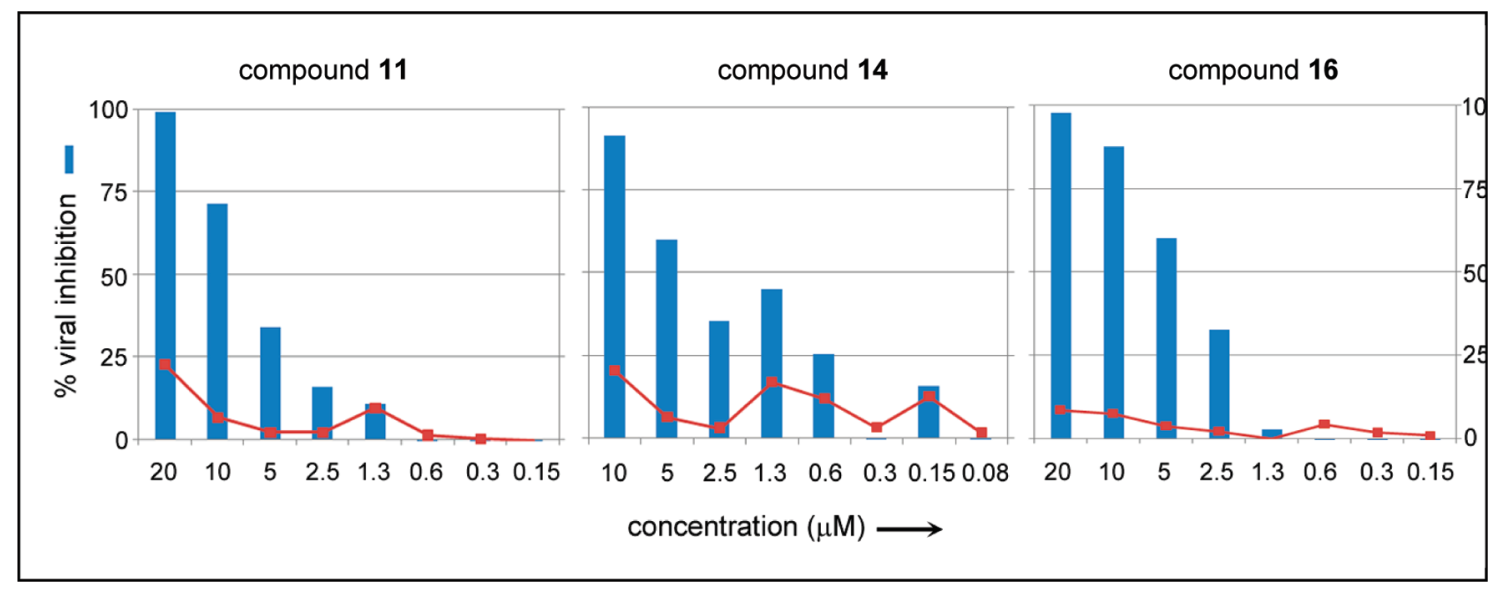

Figure 2. Dose-response results for 1,7-DAAC derivative 11-, 14-, and 16-mediated Ebola filovirus inhibition in infected Vero 76 cells (48 h incubation period).

nitrogen in piperidine and morpholine rings favors antimalarial activity, especially against drug resistant strains, without observed toxic effects. Finally, it is important to note that the inhibitory efficacies provided by the 1,7-DAAC derivatives described herein indicate that they are among the most potent SMNPIs reported to date for all three of the examined pathogenic targets.

\section{EXPERIMENTAL SECTION}

General. Melting points were determined on a Boetius PMHK apparatus and were not corrected. IR spectra were recorded on a PerkinElmer spectrophotometer FTIR $1725 \mathrm{X} .{ }^{1} \mathrm{H}$ and ${ }^{13} \mathrm{C}$ NMR spectra were recorded on a Varian Gemini-200 spectrometer (at 200 and $50 \mathrm{MHz}$, respectively) and a Bruker Ultrashield Advance III spectrometer (at 500 and $125 \mathrm{MHz}$, respectively) in the indicated solvent (vide infra) using TMS as internal standard. Chemical shifts are expressed in ppm $(\delta)$ values and coupling constants $(J)$ in Hz. ESI-MS (HRMS) spectra of synthesized compounds were acquired on a Agilent Technologies 1200 series instrument equipped with Zorbax Eclipse Plus C18 (100 mm $\times$ $2.1 \mathrm{~mm}$ i.d. $1.8 \mu \mathrm{m})$ column and DAD detector $(190-450 \mathrm{~nm})$ in combination with a 6210 time-of-flight LC/MS instrument in the positive ion mode. The samples were dissolved in pure $\mathrm{H}_{2} \mathrm{O}$ (HPLC grade). The selected values were as follows: capillary voltage $4 \mathrm{kV}$, gas temperature $350{ }^{\circ} \mathrm{C}$, drying gas $12 \mathrm{~L} \mathrm{~min}^{-1}$, nebulizer pressure $45 \mathrm{psig}$, fragmentator voltage $70 \mathrm{~V}$. Lobar LichroPrep Si $60(40-63 \mu \mathrm{m})$ or LichroPrep RP-18 columns coupled to a Waters RI 401 detector were used for preparative column chromatography. For metabolism experiments, incubations were separated on a Waters XTerra $3.5 \mu \mathrm{m}$, $2.0 \mathrm{~mm} \times 50 \mathrm{~mm} \mathrm{C18}$ column using a formic acid/acetonitrile mobile phase. Analyses were preformed using a Surveyor separations module coupled to a ThermoFinnigan TSQ AM triple quadrupole mass spectrometer. Mass spectral analyses were done using electrospray ionization in positive ion mode.

Compounds were analyzed for purity (HPLC) using a Waters 1525 HPLC dual pump system equipped with an Alltech, Select degasser system, and dual $\lambda 2487 \mathrm{UV}$-vis detector. Octadecylsilica was used as the stationary phase (Symmetry C18 analytical column, $4.6 \mathrm{~mm} \times$ $150 \mathrm{~mm}, 5 \mu \mathrm{m}$, series no. 02133627813637$)$. Eluent was made from the following solvents: $0.2 \%$ formic acid in water (A) and methanol (B). For data processing, Empower software was used. All compounds were $>95 \%$ pure (for details, see Supporting Information, S5-S44).

Diethyl ( $2(Z$ or $E), 2^{\prime}(Z$ or $\left.E)\right)-3,3^{\prime}$-[Naphthalene-1,5-diyldi(imino)]bisbut-2-enoate (3). A suspension of 1,5-diaminonaphthalene (5 g, $31.61 \mathrm{mmol}$ (commercial, Sigma-Aldrich)), ethyl acetoacetate
(40 mL, (commercial, Sigma-Aldrich)), and $p-\mathrm{TsOH}(2.38 \mathrm{~g}, 15.50 \mathrm{mmol})$ in anhyd $\mathrm{EtOH}(250 \mathrm{~mL})$ was heated to reflux in a two-neck round-bottom flask equipped with a Dean-Stark trap filled with molecular sieves (4 $\AA$ ). After heating for $4 \mathrm{~h}$ (oil bath temp. $120^{\circ} \mathrm{C}$ ) with stirring, the mixture was cooled to rt and evaporated to dryness. The crude product was triturated with $\mathrm{EtOH}$, and precipitate was collected in a Büchner funnel and dried under reduced pressure to afford $11.39 \mathrm{~g}$ (94\%) of 3 as a light-brown powder. IR (ATR): 3442, 3253, 2977, 2923, 1652, 1606, 1506, 1440, 1267, $1158,787 \mathrm{~cm}^{-1}$.

3,9-Dimethyl-4,10-dihydroquino[8,7-h]quinoline-1,7-dione (4). A mixture of $3(2 \mathrm{~g}, 5.23 \mathrm{mmol})$ and Eaton's reagent $(5.5 \mathrm{~mL}$, $29.06 \mathrm{mmol}$ (commercial, Sigma-Aldrich)) was stirred at $90^{\circ} \mathrm{C}$ for $5 \mathrm{~h}$. The reaction mixture was cooled to $5^{\circ} \mathrm{C}$ (ice bath) and carefully poured onto saturated ice-cold $\mathrm{Na}_{2} \mathrm{CO}_{3}$ solution $\left(31 \mathrm{~g} \mathrm{Na}_{2} \mathrm{CO}_{3} / 100 \mathrm{~mL} \mathrm{H}_{2} \mathrm{O}\right)$. The solid was filtered, and filtrate was washed with water $(3 \times 50 \mathrm{~mL})$, EtOH $(10 \mathrm{~mL})$, and dried under reduced pressure at $50{ }^{\circ} \mathrm{C}$ to afford $1.43 \mathrm{~g}$ (94\%) of dione 4 as a light-brown powder; $\mathrm{mp}>280^{\circ} \mathrm{C}$. IR (ATR): $3227,3169,3059,2978,1630,1601,1546,1520,1492,1434,1354,1211$, 1153, 1029, $843 \mathrm{~cm}^{-1} .{ }^{1} \mathrm{H}$ NMR $(200 \mathrm{MHz}, \mathrm{TFA}-d): 9.15(\mathrm{~d}, J=9.6 \mathrm{~Hz}$, $2 \mathrm{H}), 8.87(\mathrm{~d}, J=9.6 \mathrm{~Hz}, 2 \mathrm{H}), 7.58(\mathrm{~s}, 2 \mathrm{H}), 3.15(\mathrm{~s}, 6 \mathrm{H}) \mathrm{ppm} .{ }^{13} \mathrm{C} \mathrm{NMR}$ $(50 \mathrm{MHz}$, TFA- $d$ ): 172.18, 139.66, 130.28, 127.79, 125.15, 123.15, 121.93, 111.70, $22.27 \mathrm{ppm}$.

1,7-Dichloro-3,9-dimethylquino[8,7-h]quinoline (5). A suspension of $4(1.37 \mathrm{~g}, 4.73 \mathrm{mmol})$ in $\mathrm{POCl}_{3}(28.38 \mathrm{~mL})$ was heated at $90^{\circ} \mathrm{C}$ for $6 \mathrm{~h}$, with continued heating at $120^{\circ} \mathrm{C}$ for $14 \mathrm{~h}$. Upon cooling to rt, the mixture was slowly poured onto an ice/water mixture, and concd aq $\mathrm{NH}_{3}$ was added until $\mathrm{pH} 9$ as achieved. Formed precipitate was filtered and washed well with $\mathrm{H}_{2} \mathrm{O}$ and $\mathrm{EtOH}$. Obtained dichloride 5 was dried under reduced pressure at $60^{\circ} \mathrm{C}$. Yield: $1.4442 \mathrm{~g}(93 \%) ; \mathrm{mp}>280^{\circ} \mathrm{C}$. IR (ATR): 2922, 1582, 1481, 1432, 1359, 1083, 1027, 877, 849, 829, $749 \mathrm{~cm}^{-1} .{ }^{1} \mathrm{H}$ NMR $(200 \mathrm{MHz}, \mathrm{TFA}-d): 9.30(\mathrm{~d}, J=9.6 \mathrm{~Hz}, 2 \mathrm{H}), 8.78(\mathrm{~d}, J=9.6 \mathrm{~Hz}, 2 \mathrm{H})$, 8.18 (s, 2H), 3.10 (s, 6H) ppm. ${ }^{13} \mathrm{C}$ NMR (50 MHz, TFA-d): 162.18, $158.98,138.44,129.65,129.52,128.30,127.52,126.19,22.45$ ppm.

General Procedure for the Synthesis of 1,7-Bis(alkylamino)diazachrysene Tetrahydrochloride (1, and 6-17). A suspension of dichloride 5 ( $200 \mathrm{mg}, 0.61 \mathrm{mmol})$ in corresponding amine $(10 \mathrm{~mL})$ was stirred at reflux under argon for $60 \mathrm{~h}$. The mixture was then poured onto ice-cold water $(40 \mathrm{~mL})$, and the solid was filtered, washed well with $\mathrm{MeOH}(5 \mathrm{~mL})$, and dried at $45{ }^{\circ} \mathrm{C}$ under reduced pressure. Obtained crude base was then suspended in $\mathrm{MeOH}(12 \mathrm{~mL})$, followed by addition of $\mathrm{EtOH} / \mathrm{HCl}$ solution $(24 \mathrm{~mL}, 8.6 \mathrm{M})$, and the reaction mixture was vigorously stirred for $36 \mathrm{~h}$ at $\mathrm{rt}$. The solvent was then removed under reduced pressure, and the remaining solid was suspended in $96 \% \mathrm{EtOH}(15 \mathrm{~mL})$, filtered, and washed well with $96 \%$ 
$\mathrm{EtOH}(5 \mathrm{~mL})$ and $\mathrm{Et}_{2} \mathrm{O}(5 \mathrm{~mL})$. Upon drying at $45^{\circ} \mathrm{C}$ under reduced pressure, desired product was obtained.

N,N'-Bis(4-aminobutyl)-3,9-dimethylquino[8,7-h]quinoline-1,7diamine Tetrahydrochloride (6). Dichloride 5 (200 mg, $0.61 \mathrm{mmol}$ ) was transformed into 6 using the general procedure provided above, with corresponding amine (butane-1,4-diamine). Compound 6: yield $270.7 \mathrm{mg}(68 \%) ; \mathrm{mp}>280^{\circ} \mathrm{C}$. IR (KBr): $3455,3208,3046,1636,1609$, $1566,1504,1442,1363,1343,1290,1152,1094,1041,924,830,744 \mathrm{~cm}^{-1}$. ${ }^{1} \mathrm{H}$ NMR $\left(500 \mathrm{MHz}, \mathrm{D}_{2} \mathrm{O}\right): 8.53(\mathrm{~d}, J=9.5 \mathrm{~Hz}, 2 \mathrm{H}), 8.23(\mathrm{~d}, J=9.0 \mathrm{~Hz}$, $2 \mathrm{H}), 7.04(\mathrm{~s}, 2 \mathrm{H}), 3.90-3.80(\mathrm{~m}, 4 \mathrm{H}), 3.30-3.20(\mathrm{~m}, 4 \mathrm{H}), 2.97(\mathrm{~s}$, $6 \mathrm{H}), 2.10-2.00(\mathrm{~m}, 4 \mathrm{H})$ ppm. ${ }^{13} \mathrm{C}$ NMR $\left(125 \mathrm{MHz}, \mathrm{D}_{2} \mathrm{O}\right): 157.75$, $157.32,137.51,126.61,122.87,122.30,117.13,103.85,45.88,42.02$, 27.47, 27.24, $23.01 \mathrm{ppm}$. ESI-HRMS $(\mathrm{m} / z):[\mathrm{M}+2 \mathrm{H}]^{2+} 216.14891$ (error $-2.83 \mathrm{ppm}$ ), $[\mathrm{M}+\mathrm{H}]^{+} 431.29109$ (error $-1.58 \mathrm{ppm}$ ).

N,N'-Bis(3-aminopropyl)-3,9-dimethylquino[8,7-h]quinoline-1,7diamine Tetrahydrochloride (7). Dichloride 5 (200 mg, $0.61 \mathrm{mmol}$ ) was transformed into 7 using the general procedure provided above, with corresponding amine (propane-1,3-diamine). Compound 7: yield $194 \mathrm{mg}$ (58\%); mp > $280^{\circ} \mathrm{C}$. IR (ATR): 3378, 3178, 3021, 1636, 1608, $1559,1505,1438,1360,1291,1146,1091,1034,985,827,742 \mathrm{~cm}^{-1} \cdot{ }^{1} \mathrm{H}$ NMR $\left(200 \mathrm{MHz}, \mathrm{D}_{2} \mathrm{O}\right): 8.28(\mathrm{~d}, J=9.6 \mathrm{~Hz}, 2 \mathrm{H}), 8.07(\mathrm{~d}, J=9.6 \mathrm{~Hz}$, $2 \mathrm{H}), 7.05(\mathrm{~s}, 2 \mathrm{H}), 4.00-3.80(\mathrm{~m}, 4 \mathrm{H}), 3.45-3.30(\mathrm{~m}, 4 \mathrm{H}), 2.92(\mathrm{~s}$, $6 \mathrm{H}), 2.50-2.30(\mathrm{~m}, 4 \mathrm{H}) \mathrm{ppm} .{ }^{13} \mathrm{C}$ NMR $\left(50 \mathrm{MHz}, \mathrm{D}_{2} \mathrm{O}\right): 157.76$, 157.52, 137.33, 126.33, 122.87, 122.18, 116.97, 104.04, 43.59, 40.04, 28.50, 23.18 ppm. ESI-HRMS $(m / z):[\mathrm{M}+2 \mathrm{H}]^{2+} 202.13390$ (error $0.12 \mathrm{ppm}),[\mathrm{M}+\mathrm{H}]^{+} 403.26024$ (error $-0.58 \mathrm{ppm}$ ).

$\mathrm{N}, \mathrm{N}^{\prime}$-Bis(2-aminoethyl)-3,9-dimethylquino[8,7-h]quinoline-1,7diamine Tetrahydrochloride (8). Dichloride 5 (200 mg, $0.61 \mathrm{mmol}$ ) was transformed into $\mathbf{8}$ using the general procedure provided above, with corresponding amine (ethane-1,2-diamine). Compound 8: yield $197 \mathrm{mg}$ (62\%); mp > $280^{\circ} \mathrm{C}$. IR (ATR): 3425, 3187, 3043, 1634, 1615, $1565,1508,1440,1380,1345,1273,1159,1094,1030,950,834,745 \mathrm{~cm}^{-1}$. ${ }^{1} \mathrm{H}$ NMR $\left(200 \mathrm{MHz}, \mathrm{D}_{2} \mathrm{O}\right): 8.67(\mathrm{~d}, J=9.4 \mathrm{~Hz}, 2 \mathrm{H}), 8.32(\mathrm{~d}, J=9.4 \mathrm{~Hz}$, $2 \mathrm{H}), 7.18(\mathrm{~s}, 2 \mathrm{H}), 4.25-4.10(\mathrm{~m}, 4 \mathrm{H}), 3.70-3.50(\mathrm{~m}, 4 \mathrm{H}), 3.00(\mathrm{~s}, 6 \mathrm{H})$ ppm. ${ }^{13} \mathrm{C}$ NMR $\left(50 \mathrm{MHz}, \mathrm{D}_{2} \mathrm{O}\right): 158.31,158.21,137.80,126.97$, $123.33,122.82,117.79,104.37,43.28,40.19,23.07$ ppm. ESI-HRMS $(m / z):[\mathrm{M}+2 \mathrm{H}]^{2+} 188.11949$ (error $\left.6.73 \mathrm{ppm}\right),[\mathrm{M}+\mathrm{H}]^{+}$ 375.22869 (error $-1.29 \mathrm{ppm})$.

$\mathrm{N}, \mathrm{N}^{\prime}$-Bis[3-(dimethylamino)propyl]-3,9-dimethylquino[8,7-h]quinoline-1,7-diamine tetrahydrochloride (9). Dichloride 5 (160 mg, 0.49 $\mathrm{mmol}$ ) was transformed into 9 using the general procedure provided above, with corresponding amine ( $N, N$-dimethylpropane-1,3-diamine). Compound 9: yield $222 \mathrm{mg}$ (75\%); mp > $280^{\circ} \mathrm{C}$. IR (ATR): 3354, 3210, 2964, 2681, 2477, 1633, 1608, 1565, 1469, 1439, 1356, 1041, 830, 745 $\mathrm{cm}^{-1} .{ }^{1} \mathrm{H}$ NMR (500 MHz, CD $\left.\mathrm{OD}\right): 8.99$ (d, J = 9.5 Hz, 2H), 8.66 (d, $J=9.6 \mathrm{~Hz}, 2 \mathrm{H}), 7.16(\mathrm{~s}, 2 \mathrm{H}), 3.83-3.79(\mathrm{~m}, 4 \mathrm{H}), 3.44-3.40(\mathrm{~m}, 4 \mathrm{H})$, $2.98(\mathrm{~s}, 12 \mathrm{H}), 2.94(\mathrm{~s}, 6 \mathrm{H}) \mathrm{ppm} .{ }^{13} \mathrm{C} \mathrm{NMR}\left(125 \mathrm{MHz}, \mathrm{CD}_{3} \mathrm{OD}\right)$ : $157.03,156.76,137.09,126.26,122.57,121.64,116.73,103.00,56.57$, 43.77, 42.02, 24.75, 21.12 ppm. ESI-HRMS $(m / z):[\mathrm{M}+2 \mathrm{H}]^{2+}$ 230.16557 (error $1.72 \mathrm{ppm}$ ), $[\mathrm{M}+\mathrm{H}]^{+} 459.32310$ (error $0.07 \mathrm{ppm}$ ).

$N, N^{\prime}$-Bis[2-(dimethylamino)ethyl]-3,9-dimethylquino[8,7-h]quinoline-1,7-diamine Tetrahydrochloride (10). Dichloride 5 (300 mg, 0.92 $\mathrm{mmol}$ ) was transformed into $\mathbf{1 0}$ using the general procedure provided above, with corresponding amine (N,N-dimethylethane-1,2-diamine). Compound 10: yield $366 \mathrm{mg}$ (69\%); mp > $280^{\circ} \mathrm{C}$. IR (ATR): 3430, 3361, 3180, 3068, 3029, 2974, 2699, 1634, 1609, 1554, 1445, 1344, 988, $828,746 \mathrm{~cm}^{-1} .{ }^{1} \mathrm{H}$ NMR $\left(200 \mathrm{MHz}, \mathrm{D}_{2} \mathrm{O}\right): 8.69(\mathrm{~d}, J=9.6 \mathrm{~Hz}, 2 \mathrm{H})$, 8.39 (d, $J=9.6 \mathrm{~Hz}, 2 \mathrm{H}), 7.24(\mathrm{~s}, 2 \mathrm{H}), 4.34-4.20(\mathrm{~m}, 4 \mathrm{H}), 3.89-3.78$ (m, 4H), 3.22 (s, 12H), $3.02(\mathrm{~s}, 6 \mathrm{H})$ ppm. ${ }^{13} \mathrm{C}$ NMR $\left(50 \mathrm{MHz}, \mathrm{D}_{2} \mathrm{O}\right)$ : $158.40,138.50,127.77,123.58,123.22$, 118.57, 104.57, 57.56, 57.14, 46.01, 41.02, 23.00, 21.85, 17.74 ppm. ESI-HRMS $(m / z):[\mathrm{M}+2 \mathrm{H}]^{2+}$ 216.14969 (error $0.78 \mathrm{ppm}$ ), $[\mathrm{M}+\mathrm{H}]^{+} 431.29161$ (error $0.37 \mathrm{ppm}$ ).

N,N'-Bis[3-(diethylamino)propyl]-3,9-dimethylquino[8,7-h]quinoline-1,7-diamine Tetrahydrochloride (1). Dichloride 5 (160 mg,
$0.49 \mathrm{mmol}$ ) was transformed into 1 using the general procedure provided above, with corresponding amine ( $N, N$-diethylpropane-1,3diamine). Compound 1: yield $210 \mathrm{mg}(65 \%) ; \mathrm{mp}>280^{\circ} \mathrm{C}$. IR (ATR): 3164, 2949, 2575, 2478, 1632, 1610, 1560, 1468, 1439, 1347, 1030, 821, $750 \mathrm{~cm}^{-1}$. ${ }^{1} \mathrm{H}$ NMR $\left(500 \mathrm{MHz}, \mathrm{CD}_{3} \mathrm{OD}\right): 9.07(\mathrm{~d}, J=9.5 \mathrm{~Hz}, 2 \mathrm{H}), 8.74$ $(\mathrm{d}, J=9.5 \mathrm{~Hz}, 2 \mathrm{H}), 7.20(\mathrm{~s}, 2 \mathrm{H}), 3.83-3.80(\mathrm{~m}, 4 \mathrm{H}), 3.40-3.38(\mathrm{~m}$, $4 \mathrm{H}), 2.96(\mathrm{~s}, 12 \mathrm{H}), 2.35-2.29(\mathrm{~m}, 4 \mathrm{H}), 1.38(\mathrm{t}, J=7.2 \mathrm{~Hz}, 12 \mathrm{H}) \mathrm{ppm}$. ${ }^{13} \mathrm{C}$ NMR (125 MHz, CD $\left.{ }_{3} \mathrm{OD}\right): 157.20,156.75,137.19,126.41,122.66$, $121.72,116.87,103.02,50.98,48.71,24.24,21.03,9.36$ ppm. ESI-HRMS $(\mathrm{m} / z):[\mathrm{M}+2 \mathrm{H}]^{2+} 258.19756$ (error $\left.2.08 \mathrm{ppm}\right),[\mathrm{M}+\mathrm{H}]^{+}$ 515.38770 (error $0.36 \mathrm{ppm}$ ).

$\mathrm{N}, \mathrm{N}^{\prime}$-Bis[2-(diethylamino)ethyl]-3,9-dimethylquino[8,7-h]quinoline-1,7-diamine Tetrahydrochloride (11). Dichloride 5 (200 mg, 0.61 $\mathrm{mmol}$ ) was transformed into 11 using the general procedure provided above, with corresponding amine ( $N, N$-diethylethane-1,2-diamine). Compound 11: yield $212 \mathrm{mg}$ (55\%); mp > $280^{\circ} \mathrm{C}$. IR (ATR): 3384, $3188,3066,2663,1635,1610,1556,1441,1348,1071,830,744 \mathrm{~cm}^{-1}$. ${ }^{1} \mathrm{H}$ NMR (500 MHz, CD $\left.3 \mathrm{OD}\right): 9.14(\mathrm{~d}, J=9.0 \mathrm{~Hz}, 2 \mathrm{H}), 8.85$ (d, $J=9.0$ $\mathrm{Hz}, 2 \mathrm{H}), 7.30(\mathrm{~s}, 2 \mathrm{H}), 4.18-4.14(\mathrm{~m}, 4 \mathrm{H}), 3.68-3.63(\mathrm{~m}, 4 \mathrm{H})$, $3.46-3.38(\mathrm{~m}, 8 \mathrm{H}), 2.97(\mathrm{~s}, 6 \mathrm{H}), 1.44-1.40(\mathrm{~m}, 12 \mathrm{H}) \mathrm{ppm} .{ }^{13} \mathrm{C}$ NMR (125 MHz, CD $\left.{ }_{3} \mathrm{OD}\right): 157.37,157.22,137.49,126.68,123.01$, $121.88,117.29,103.41,51.11,39.68,21.05,9.16$ ppm. ESI-HRMS ( $/$ $z):[\mathrm{M}+2 \mathrm{H}]^{2+} 244.18208$ (error $\left.5.13 \mathrm{ppm}\right),[\mathrm{M}+\mathrm{H}]^{+} 487.35548$ (error $2.28 \mathrm{ppm}$ ).

3,9-Dimethyl-N, N'-bis(3-pyrrolidin-1-ylpropyl)quino[8,7-h]quinoline-1,7-diamine Tetrahydrochloride (12). Dichloride 5 (200 mg, 0.61 $\mathrm{mmol}$ ) was transformed into $\mathbf{1 2}$ using the general procedure provided above, with corresponding amine ((3-pyrrolidin-1-ylpropyl)amine). Compound 12: yield $255 \mathrm{mg}$ (76\%); $\mathrm{mp}>280^{\circ} \mathrm{C}$. IR (ATR): 3410 , 3079, 2960, 2762, 1639, 1612, 1565, 1509, 1441, 1362, 1168, 1086, 1042, 831, $744 \mathrm{~cm}^{-1} .{ }^{1} \mathrm{H}$ NMR $\left(200 \mathrm{MHz}, \mathrm{D}_{2} \mathrm{O}\right): 8.51(\mathrm{~d}, J=9.6 \mathrm{~Hz}, 2 \mathrm{H})$, $8.23(\mathrm{~d}, J=9.6 \mathrm{~Hz}, 2 \mathrm{H}), 7.14(\mathrm{~s}, 2 \mathrm{H}), 4.00-3.80(\mathrm{~m}, 8 \mathrm{H}), 3.70-3.50$ (m, 4H), 3.40-3.20 (m, 4H), $2.99(\mathrm{~s}, 6 \mathrm{H}), 2.60-2.10(\mathrm{~m}, 12 \mathrm{H}) \mathrm{ppm}$. ${ }^{13} \mathrm{C}$ NMR $\left(50 \mathrm{MHz}, \mathrm{D}_{2} \mathrm{O}\right): 157.80,137.46,126.57,123.05,122.45$, 117.26, 104.08, 57.17, 55.10, 43.41, 27.22, 25.51, 23.03 ppm. ${ }^{1} \mathrm{H}$ NMR $\left(500 \mathrm{MHz}, \mathrm{D}_{2} \mathrm{O}\right): 8.55(\mathrm{~d}, J=9.5 \mathrm{~Hz}, 2 \mathrm{H}), 8.26(\mathrm{~d}, J=9.5 \mathrm{~Hz}, 2 \mathrm{H}), 7.13$ (s, $2 \mathrm{H}), 3.95-3.90(\mathrm{~m}, 8 \mathrm{H}), 3.65-3.55(\mathrm{~m}, 4 \mathrm{H}), 3.35-3.30(\mathrm{~m}, 4 \mathrm{H})$, $3.01(\mathrm{~s}, 6 \mathrm{H}), 2.50-2.40(\mathrm{~m}, 4 \mathrm{H}), 2.40-2.30(\mathrm{~m}, 4 \mathrm{H}), 2.25-2.15(\mathrm{~m}$, $4 \mathrm{H}) \mathrm{ppm} .{ }^{13} \mathrm{C}$ NMR $\left(125 \mathrm{MHz}, \mathrm{D}_{2} \mathrm{O}\right): 154.68,154.57,134.39,123.52$, $119.83,119.32,114.16,100.86,54.05,51.98,40.24,24.10,22.39,19.92$ ppm. ESI-HRMS $(\mathrm{m} / z):[\mathrm{M}+2 \mathrm{H}]^{2+} 256.18065$ (error $\left.-0.66 \mathrm{ppm}\right)$, $[\mathrm{M}+\mathrm{H}]^{+} 511.35409$ (error $\left.-0.55 \mathrm{ppm}\right)$.

3,9-Dimethyl-N, $N^{\prime}$-bis(2-pyrrolidin-1-ylethyl)quino[8,7-h]quinoline-1,7-diamine Tetrahydrochloride (13). Dichloride 5 ( $250 \mathrm{mg}, 0.76$ $\mathrm{mmol}$ ) was transformed into $\mathbf{1 3}$ using the general procedure provided above, with corresponding amine ((2-pyrrolidin-1-ylethyl)amine). Compound 13: yield $302 \mathrm{mg}$ (68\%); mp > $280^{\circ} \mathrm{C}$. IR (ATR): 3418, $3225,3066,2709,1635,1611,1556,1510,1441,1346,1031,828$, $745 \mathrm{~cm}^{-1} .{ }^{1} \mathrm{H}$ NMR $\left(200 \mathrm{MHz}, \mathrm{D}_{2} \mathrm{O}\right): 8.87(\mathrm{~d}, J=9.6 \mathrm{~Hz}, 2 \mathrm{H}), 8.48(\mathrm{~d}$, $J=9.6 \mathrm{~Hz}, 2 \mathrm{H}), 7.20(\mathrm{~s}, 2 \mathrm{H}), 4.40-4.20(\mathrm{~m}, 4 \mathrm{H}), 4.05-3.70(\mathrm{~m}, 8 \mathrm{H})$, $3.50-3.10(\mathrm{~m}, 4 \mathrm{H}), 3.02(\mathrm{~s}, 6 \mathrm{H}), 2.40-2.00(\mathrm{~m}, 8 \mathrm{H}) \mathrm{ppm} .{ }^{13} \mathrm{C} \mathrm{NMR}$ $\left(50 \mathrm{MHz}, \mathrm{D}_{2} \mathrm{O}\right): 158.36,138.20,127.41,123.53,123.04,118.19,104.50$, $57.54,54.88,42.23,25.55,23.03$ ppm. ESI-HRMS $(m / z):[\mathrm{M}+2 \mathrm{H}]^{2+}$ 242.16524 (error $0.27 \mathrm{ppm}$ ), $[\mathrm{M}+\mathrm{H}]^{+} 483.32241$ (error $-1.36 \mathrm{ppm}$ ).

3,9-Dimethyl-N, $N^{\prime}$-bis(3-piperidin-1-ylpropyl)quino[8,7-h]quinoline-1,7-diamine Tetrahydrochloride (14). Dichloride 5 (200 mg, 0.61 $\mathrm{mmol}$ ) was transformed into $\mathbf{1 4}$ using the general procedure provided above, with corresponding amine ((3-piperidin-1-ylpropyl)amine). Compound 14: yield $330 \mathrm{mg}$ (79\%); $\mathrm{mp} \mathrm{>} 280^{\circ} \mathrm{C}$. IR (ATR): 3361, $3182,2944,2536,1636,1606,1562,1438,1354,835,745 \mathrm{~cm}^{-1} .{ }^{1} \mathrm{H}$ $\operatorname{NMR}\left(500 \mathrm{MHz}, \mathrm{CD}_{3} \mathrm{OD}\right): 9.11(\mathrm{~d}, J=8.5 \mathrm{~Hz}, 2 \mathrm{H}), 8.77(\mathrm{~d}, J=8.5 \mathrm{~Hz}$, $2 \mathrm{H}), 7.18(\mathrm{~s}, 2 \mathrm{H}), 3.83-3.79(\mathrm{~m}, 4 \mathrm{H}), 3.62(\mathrm{bd}, J=12 \mathrm{~Hz}, 4 \mathrm{H})$, 3.37-3.30 (m, 4H), 3.07-2.95 (m, 4H), $2.95(\mathrm{~s}, 6 \mathrm{H}), 2.39-2.32$ (m, 4H), $2.00-1.84(\mathrm{~m}, 10 \mathrm{H}), 1.59-1.51(\mathrm{~m}, 2 \mathrm{H}) \mathrm{ppm} .{ }^{13} \mathrm{C}$ NMR 
(125 MHz, $\left.\mathrm{CD}_{3} \mathrm{OD}\right): 157.29,156.73,137.27,126.55,122.71,121.69$, 116.96, 55.75, 54.64, 42.12, 24.43, 24.12, 22.86, 20.97 ppm. ESI-HRMS $(m / z):[\mathrm{M}+2 \mathrm{H}]^{2+} 270.19601$ (error $1.73 \mathrm{ppm}$ ), $[\mathrm{M}+\mathrm{H}]^{+}$ 539.38481 (error $1.61 \mathrm{ppm})$.

3,9-Dimethyl-N,N'-bis(2-piperidin-1-ylethyl)quino[8,7-h]quinoline1,7-diamine Tetrahydrochloride (15). Dichloride 5 (200 mg, 0.61 $\mathrm{mmol})$ was transformed into $\mathbf{1 5}$ using the general procedure provided above, with corresponding amine ((2-piperidin-1-ylethyl)amine). Compound 15: yield $224 \mathrm{mg}(56 \%) ; \mathrm{mp}>280^{\circ} \mathrm{C}$. IR (ATR): 3345, 3224, 2943, 2644, 1634, 1608, 1564, 1438, 1360, 831, $744 \mathrm{~cm}^{-1} .{ }^{1} \mathrm{H}$ NMR $\left(500 \mathrm{MHz}, \mathrm{D}_{2} \mathrm{O}\right): 8.86(\mathrm{~d}, J=9.5 \mathrm{~Hz}, 2 \mathrm{H}), 8.48(\mathrm{~d}, J=9.5 \mathrm{~Hz}, 2 \mathrm{H}), 7.19$ (s, $2 \mathrm{H}), 4.29-4.24(\mathrm{~m}, 4 \mathrm{H}), 3.83(\mathrm{bd}, J=12 \mathrm{~Hz}, 4 \mathrm{H}), 3.74-3.70(\mathrm{~m}$, $4 \mathrm{H}), 3.27-3.21(\mathrm{~m}, 4 \mathrm{H}), 3.02(\mathrm{~s}, 6 \mathrm{H}), 2.15-2.10(\mathrm{~m}, 4 \mathrm{H}), 2.01-1.92$ (m, 6H), 1.59-1.52 (m, 2H) ppm. ${ }^{13} \mathrm{C}$ NMR $\left(125 \mathrm{MHz}, \mathrm{D}_{2} \mathrm{O}\right): 158.28$, $158.21,138.14,127.37,123.45,122.95,118.13,104.39,56.63,40.54$, 25.57, 23.81, 23.03 ppm. ESI-HRMS $(\mathrm{m} / z):[\mathrm{M}+2 \mathrm{H}]^{2+} 256.18169$ (error $3.38 \mathrm{ppm}$ ), $[\mathrm{M}+\mathrm{H}]^{+} 511.35584$ (error $2.87 \mathrm{ppm}$ ).

3,9-Dimethyl-N, $N^{\prime}$-bis (3-morpholin-4-ylpropyl)quino[8,7-h]quinoline-1, 7-diamine Tetrahydrochloride (16). Dichloride 5 (200 mg, $0.61 \mathrm{mmol}$ ) was transformed into $\mathbf{1 6}$ using the general procedure provided above, with corresponding amine ((3-morpholin-4-ylpropyl)amine). Compound 16: yield $211 \mathrm{mg}(67 \%) ; \mathrm{mp}>280^{\circ} \mathrm{C}$. IR (ATR): 3344, 3220, 3074, 2942, 2684, 2613, 2471, 1636, 1609, 1564, 1508, 1439, 1356, 1306, 1263, 1217, 1135, 1105, 1045, 963, 908, 862, 833, $744 \mathrm{~cm}^{-1} .{ }^{1} \mathrm{H} \mathrm{NMR}(200 \mathrm{MHz}$, $\left.\mathrm{D}_{2} \mathrm{O}\right): 8.46(\mathrm{~d}, J=9 \mathrm{~Hz}, 2 \mathrm{H}), 8.21(\mathrm{~d}, J=9 \mathrm{~Hz}, 2 \mathrm{H}), 7.15(\mathrm{~s}, 2 \mathrm{H}), 4.40-$ $3.40(\mathrm{~m}, 24 \mathrm{H}), 2.98(\mathrm{~s}, 6 \mathrm{H}), 2.60-2.30(\mathrm{~m}, 4 \mathrm{H}) \mathrm{ppm} .{ }^{13} \mathrm{C} \mathrm{NMR}$ $\left(50 \mathrm{MHz}, \mathrm{D}_{2} \mathrm{O}\right): 157.78,137.38,126.48,123.07,122.42,117.25,104.17$, 66.72, 57.41, 54.79, 43.37, 25.07, 23.07 ppm. ESI-HRMS $(\mathrm{m} / z):[\mathrm{M}+$ $2 \mathrm{H}]^{2+} 272.17515$ (error $-2.18 \mathrm{ppm}$ ), $[\mathrm{M}+\mathrm{H}]^{+} 543.34189$ (error $4.25 \mathrm{ppm})$.

3,9-Dimethyl- $N, N^{\prime}$-bis(2-morpholin-4-ylethyl)quino[8,7-h]quinoline-1,7-diamine Tetrahydrochloride (17). Dichloride 5 (270 mg, 0.82 $\mathrm{mmol}$ ) was transformed into $\mathbf{1 7}$ using the general procedure provided above, with corresponding amine ((2-morpholin-4-ylethyl)amine). Compound 17: yield $417 \mathrm{mg}$ (88\%); $\mathrm{mp}>280{ }^{\circ} \mathrm{C}$. IR (ATR): 3482 , 3411, 3183, 3072, 2873, 2567, 2442, 1637, 1613, 1559, 1511, 1442, 1347, 1302, 1267, 1232, 1175, 1133, 1102, 1043, 906, 826, $744 \mathrm{~cm}^{-1} \cdot{ }^{1} \mathrm{H}$ NMR (200 MHz, $\left.\mathrm{D}_{2} \mathrm{O}\right): 8.91(\mathrm{~d}, J=9.6 \mathrm{~Hz}, 2 \mathrm{H}), 8.51(\mathrm{~d}, J=9.6 \mathrm{~Hz}$, $2 \mathrm{H}), 7.20(\mathrm{~s}, 2 \mathrm{H}), 4.40-4.10(\mathrm{~m}, 12 \mathrm{H}), 3.90-3.50(\mathrm{~m}, 12 \mathrm{H}), 3.03(\mathrm{~s}$, $6 \mathrm{H}) \mathrm{ppm} .{ }^{13} \mathrm{C}$ NMR $\left(50 \mathrm{MHz}, \mathrm{D}_{2} \mathrm{O}\right): 157.41,137.40,126.60,122.54$, $122.09,117.32,103.50,65.63,56.16,54.09,39.21,22.12$ ppm. ESIHRMS $(m / z):[\mathrm{M}+2 \mathrm{H}]^{2+} 258.16032($ error $0.91 \mathrm{ppm}),[\mathrm{M}+\mathrm{H}]^{+}$ 515.31241 (error $-0.95 \mathrm{ppm}$ ).

Molecular Modeling (for Figure 1 SMNPI Superimpositions). Insight II (v2005) (Accelrys, San Diego, USA) was used to perform all molecular modeling. The structures of 1,2 , and CQ were generated using the Builder module. Following, 1, 2, and CQ were each energy minimized employing the Discover module (ccf91 forcefield, distance dependent dielectic $=1$ ). For each SMNPI, steepest descent minimization was performed for 500 iterations, followed by conjugate gradient minimization until the norm of the derivative was $0.001 \mathrm{kcal} / \AA$. SMNPIs were manually superimposed to achieve optimal steric and atomic superimpositions (i.e., via translational, rotational, and bond torsion adjustments).

In Vitro BoNT/A LC Metalloprotease Activity. Determination of BoNT/A LC percent inhibition by SMNPIs was performed as previously described, ${ }^{31-33,36 \mathrm{~b}-36 \mathrm{~d}, 36 \mathrm{f}, 37}$ The assay uses an $\mathrm{N}$-terminal acetylated, $C$-terminal aminated, synthetic peptide with the same sequence as residues 187-203 of SNAP-25. Because substrate hydrolysis is determined by HPLC separation of the products from the substrate, and is followed by measuring peak areas, intrinsic compound fluorescence quenching does not interfere with inhibition measurements. Assay mixtures contained $40 \mathrm{mM}$ HEPES $-0.05 \%$ Tween $(\mathrm{pH}$ 7.3), recombinant BoNT/A LC, peptide substrate, $0.5 \mathrm{mg} / \mathrm{mL}$ bovine serum albumin (BSA), and various SMNPI concentrations. The assay was run at $37^{\circ} \mathrm{C}$, quenched by the addition of TFA, and analyzed using reverse-phase HPLC. Excess $\mathrm{ZnCl}_{2}(50 \mu \mathrm{M})$ was added to the assay to ensure that the SMNPIs were not $\mathrm{Zn}$ (II) chelators. Measurements of percent inhibition were performed in duplicate. The calculated $K_{\mathrm{i}}$ values were determined based on the slopes of Dixon plots where $K_{\mathrm{i}}=$ $K_{\mathrm{m}} /\left(\right.$ slope $\left.\times V_{\max } \times S\right) . S=$ the substrate conc. The reported $K_{\mathrm{i}}$ values are the averages of three separate experiments incorporating nine concentrations of SMNPI.

In Vitro Antimalarial Activity. The in vitro antimalarial drug susceptibility screen is a modification of the procedures first published by Desjardins et al.; ${ }^{45}$ the modifications were developed by Milhous et al. ${ }^{46}$ Modification details are provided in ref 38. All SMNPIs were screened in vitro against $P$. falciparum strains: $C Q$ and MFQ susceptible strain D6 (a clone of the Sierra I/UNC isolate), CQ resistant but MFQ susceptible strain W2 (a clone of the Indochina I isolate), and CQ and MFQ resistant strain TM91C235 (C235, a clone of a South-East Asian isolate).

In Vivo Antimalarial Efficacy Studies. The two mouse (Mus musculus, ICR stock) antimalarial efficacy screens for blood and exoerythrocytic stages of infection were conducted at the United States Army Medical Component, Armed Forces Research Institute of Medical Sciences (USAMC-AFRIMS) in Bangkok, Thailand. Study protocols were approved by the USAMC-AFRIMS Institutional Animal Care and Use Committee. Animals were cared for in accordance with the "Guide for the Care and Use of Laboratory Animals" published by the National Research Council, 1996. The USAMC-AFRIMS' animal care and use program has been accredited by the Association for the Assessment and Accreditation of Animal Care International (AAALAC International).

Briefly, for the blood-stage model, groups of five mice were inoculated intraperitoneally on day 0 with $1.0 \times 10^{6} \mathrm{P}$. berghei (P Line) (parasitized erythrocytes were obtained from infected donor mice). SMNPIs were suspended in $0.5 \%$ hydroxyethylcellulose: $0.1 \%$ Tween 80 (HECT) and administered orally once daily for three consecutive days (beginning on day 3 postinfection). Untreated vehicle control mice succumbed to infection on days 6-8 (postinfection). Blood smear samples were obtained from each animal to determine parasitemia by snipping the tip of the tail for thick and thin blood films on two microscope glass slides on study days $0,3,6,10,13,17,20,24,27$, and 31 (postinfection). Blood smear samples on glass slides were fixed in methanol and stained with Giemsa stain. Thick films, to determine the presence or absence of parasite, under oil-immersion light microscopy objective, were examined first. If positive, the thin films were then examined for the detection of malaria infected erythrocytes (percent parasitemia) by counting a total of 500 erythrocytes (at $>1 \%$ ), 1000 erythrocytes (at $<1 \%$ ), 10000 erythrocytes (at $<0.1 \%)$, and 50000 erythrocytes $(<0.01 \%)$. Mice were observed twice daily for clinical signs and individual weights were obtained on days $0,3-7,10,13,17,20,24,27$, and 31 . Mice were humanely euthanized if showing moribund condition (i.e., unable to move), and two blood smears were obtained prior to euthanasia. Cure was defined as survival until day 31 post-SMNPI treatment, with no evidence of blood parasite and without evidence of malaria infection upon necropsy (i.e., common gross necropsy lesions).

For the exoerythrocytic model, infected sporozoites were harvested from laboratory-raised Anopheles dirus mosquitoes that were fed on donor mice infected with P. berghei (ANKA strain) at $>8 \%$ parasitemia, with the presence of gametocytes. After incubating the mosquitoes at $19{ }^{\circ} \mathrm{C}$ for a minimum of 18 days, the mosquito salivary glands were dissected and suspended in phosphate buffered saline with 5\% BSA. The fresh sporozoite suspension was counted for 100 microscopic fields using a hemacytometer under phase-contrast microscopy to determine the number of sporozoites per $\mathrm{mL}$. All mice were randomized into groups (one vehicle control group and up to 10 experimental groups) as required. SMNPIs were suspended in $0.5 \%$ hydroxyethylcellulose: $0.1 \%$ Tween 80 (HECT). On day -1 , day 0 (within 1 to $3 \mathrm{~h}$ prior to 
inoculation), and day 1 , each mouse in each test group received SMNPI at the determined dose by plastic oral gavage tubes. Control animals received the same amount of the vehicle without SMNPI. On day 0, all mice were infected by a standard $0.1 \mathrm{~mL}$ dose of $1.0 \times 10^{5} \mathrm{P}$. berghei (ANKA strain) sporozoites by intravenous (IV) inoculation. Animal weights were obtained on study days $-1,0,1,6,10,15,21$, and 31 . Blood smear samples were obtained by snipping the tip of the tail for thick and thin blood films on two microscope glass slides from each animal on study days $4,5,6,7,10,15,21$, and 31 postinfection (to determine parasitemia). Blood smear samples on glass slides were fixed in methanol and stained with Giemsa stain. Thick films for the presence or absence of parasite, under oil-immersion light microscopy, were examined first. If positive, then thin films were examined for the detection of malaria infected erythrocytes (percent parasitemia) by counting a total of 500 erythrocytes (at $>1 \%$ ), 1000 erythrocytes (at $<1 \%$ ), 10000 erythrocytes (at $<0.1 \%$ ), and 50000 erythrocytes (at $<0.01 \%$ ). On day 5 and afterward, any animal with parasitemia exceeding $5 \%$ was euthanized. Mice were observed twice daily for clinical signs and mortality. Mortality and clinical signs were recorded. During days 10 and 31, if any clinical sign was observed, two blood smears were obtained. If parasitemia was detected, blood smears were conducted 2-3 times weekly. Moribund animals showing combined clinical signs within the early end point criteria (i.e., unable to move or severe depression with reduced appetite, extreme pallor, and ruffled hair) were euthanized by employing $\mathrm{CO}_{2}$. Prior to euthanasia, two blood smears were obtained for parasitemia determination. Mice surviving to day 31 were euthanized by $\mathrm{CO}_{2}$. All mice underwent necroscopy. SMNPIs, at tested doses, were considered causal prophylactics against malarial infection if the animals in that test group did not develop parasitemia within 10 days postinfection, and blood smear results remained negative throughout the 31 day experiment.

In Vitro Metabolism. Metabolic stability assay sample preparation was performed in a 96-well plate format using a TECAN Genesis robotic sample processor following WRAIR SOP SP 01-09. All incubations were carried out in $0.1 \mathrm{M}$ sodium phosphate buffer $(\mathrm{pH}$ 7.4 ) in the presence of an NADPH-regenerating system (NADP+ sodium salt, $\mathrm{MgCl}_{2} \cdot 6 \mathrm{H}_{2} \mathrm{O}$, and glucose-6-phosphate). SMNPIs $(10 \mu \mathrm{M})$, microsomes $(1 \mathrm{mg} / \mathrm{mL}$ total protein $)$, buffer, and NADPHregenerating system were warmed to $37^{\circ} \mathrm{C}$, and the reaction was initiated by the addition of glucose-6-phosphate dehydrogenase (G6PD). Samples were quenched at 0, 10, 30, and 60 min using an equal volume of cold acetonitrile. Samples were centrifuged to pellet the proteins, and the supernatant was analyzed by LC-MS/MS using fast LC gradient methods. Depletion of parent SMNPI signal was monitored relative to signal at time 0 . Chromatograms were analyzed using the mass spectrometry software Xcalibur QuanBrowser. To calculate SMNPI half-lives, a first-order rate of decay was assumed. A plot of the natural log (LN) of the compound concentration versus time was generated in which the slope of that line was $-k$. Half-lives were calculated as $0.693 / k$. Hepatic microsomal intrinsic clearance was calculated using the formula $\mathrm{CL}_{\text {int,in vitro }}=($ rate $/ \mathrm{min}) \times(\mathrm{mL} / 0.5 \mathrm{~g}) \times 52.5 \mathrm{mg} / \mathrm{g}$ liver or $\mathrm{CL}_{\text {int,in vitro }}=$ $k \times$ (microsomal protein content per gram of liver) $/$ (microsomal protein concentration in incubation buffer).

In Vitro Toxicity: Assessment of SMNPI Toxicity in a RAW 264.7 (Rat Macrophage) Cell Line. Macrophage cell line RAW 264.7 was obtained from the American Type Culture Collection and was cultured as previously described. ${ }^{52}$ All steps of the experimental procedure were performed using a Biomek 2000 robot. Then 96-well plates were seeded with $2.5 \times 104$ cells per well in $170 \mu \mathrm{L}$ of culture medium approximately $12 \mathrm{~h}$ before the start of the assay. The following morning, cells were exposed to different SMNPI concentrations ranging from 0.29 to $48 \mu \mathrm{g} / \mathrm{mL}$ and were incubated at $37^{\circ} \mathrm{C}, 5 \% \mathrm{CO}_{2}$, for $48 \mathrm{~h}$. Cell viability was assessed using the MTT (thiazolyl blue reduction) method as previously described. ${ }^{52}$ Each assay plate included a background, a target, and a DMSO control. All experiments were run in duplicate, and
$50 \%$ inhibitory concentrations $\left(\mathrm{IC}_{50}\right)$ were determined using GraphPad Prism (sigmoidal dose-response, variable slope).

$\boldsymbol{\beta}$-Hematin Inhibitory Activity Assay. The inhibition of $\beta$ hematin formation by SMNPIs 12, 15, and 16 was carried out using a $\beta$ hematin inhibitory activity (BHIA) assay. The full details of the assay have been published, ${ }^{39}$ and the assay was performed exactly as described in the indicated reference.

Antiviral Studies. The cell culture employed: Vero76 (African green monkey kidney) cells (ATCC CRL-1587) were grown in Dulbecco's Minimal Essential Medium with low bicarbonate, $10 \%$ fetal bovine serum, $1 \mathrm{mM}$ sodium pyruvate, and $1 \%$ non essential amino acid.

Recombinant Zaire Ebola virus (EBOV) engineered to express the enhanced GFP (EBOV-eGFP) gene was a kind gift from Dr. Stuart Nichol (CDC, Atlanta). The generation and characterization of this virus has been described elsewhere. ${ }^{47}$ The EBOV-eGFP virus was propagated in Vero76 cells and viral titer was determined using a standard plaque assay. ${ }^{48}$

The details of the Ebola-eGFP infection assay are described elsewhere. ${ }^{49}$ Briefly, Vero 76 cells $\left(4 \times 10^{4}\right.$ cells/well $)$ were seeded in 96-well BD high content imaging plates (BD Biosciences) and allowed to incubate overnight. For primary screening of the SMNPIs, the cells were pretreated with a single concentration $(10$ or $20 \mu \mathrm{M})$ for $2 \mathrm{~h}$ and then infected in the presence of SMNPI with EBOV-eGFP at a multiplicity of infection (MOI) of 5 . After incubation for $48 \mathrm{~h}$ at $37^{\circ} \mathrm{C}$ under $5 \% \mathrm{CO}_{2}$, the cells were fixed in $10 \%$ formalin for 3 days and then washed three times with phosphate buffered saline (PBS). Cells infected with Ebola-eGFP were stained with HCS Cellmask Deep Red cytoplasmic/ nuclear stain (Invitrogen, $5 \mu \mathrm{g} / \mathrm{mL}$ diluted in PBS) and nuclear Hoechst dye 33342 (Invitrogen, $1 \mu \mathrm{g} / \mathrm{mL}$ diluted in PBS).

For dose-response studies, SMNPIs were diluted 2-fold and incubated with the cells in the presence of Ebola-eGFP as described elsewhere. ${ }^{49}$ For both of the viral infection assays, automated image acquisition of the plates were performed using an Opera confocal reader (model 3842-quadruple excitation high sensitivity (QEHS), PerkinElmer, Waltham, MA 02451). The images were analyzed within the Opera environment using standard Acapella scripts.

\section{ASSOCIATED CONTENT}

S Supporting Information. Plots of the BoNT/A LC inhibition kinetics for 7 and 8. Plots of the dose-dependent inhibition of $\beta$-hematin formation by $13,16,17$, and CQ. The in vitro cytotoxicities of 1,7 -DAAC SMNPIs versus the RAW 264.7 (mouse macrophage) cell line and corresponding selectivity indices. Antiviral inhibition provided by select 1,7-DAAC SMNPIs (primary screen data, \% inhibition at $20 \mu \mathrm{M}$ SMNPI conc. Analytical data (combustion analyses (p S4) and HPLC analyses for purity (pp S5-S44) for synthesized/isolated 1,7DAAC SMNPIs. This material is available free of charge via the Internet at http://pubs.acs.org.

\section{AUTHOR INFORMATION}

\section{Corresponding Author}

*For B.S.: phone, +381-11-263-86-06; fax, +381-11-263-60-61; E-mail, bsolaja@chem.bg.ac.rs. For J.C.B.: phone, 00-1-804-2250527; fax, 00-1-804-828-8566; E-mail, burnettjames@mail.nih. gov. For S.B.: phone, 00-1-301-619-4246; fax, 00-1-301-6192348; E-mail, sina.bavari@us.army.mil.

\section{ACKNOWLEDGMENT}

This research was supported by: (1) NATO's Public Diplomacy Division in the framework of "Science for Peace" project 
SfP983638, (2) Defense Threat Reduction Agency project 3.10084 09 RD B (and also Agreement Y3CM 100505 (MRMC and NCI, National Institutes of Health), and (3) the Ministry of Science and Technological Development of Serbia (grant no. 172008) and the Serbian Academy of Sciences and Arts. The content of this publication does not necessarily reflect the views or policies of the U.S. Department of Health and Human Services, nor does the mention of trade names, commercial products, or organizations imply endorsement by the U.S. Government or the U.S. Army. The contents of this manuscript have been reviewed by the Walter Reed Army Institute of Research. There is no objection to its presentation or publication. The opinions or assertions contained herein are the private views of the authors and are not to be construed as official or as reflecting true views of the U.S. Department of the Army, Department of Defense, or National Institutes of Health. For J. C.B., in accordance with SAIC-Frederick, Inc. contractual requirements, the following statement must be included: this project has been funded in whole or in part with federal funds from the National Cancer Institute, National Institutes of Health, under contract no. HHSN261200800001E.

\section{ABBREVIATIONS USED}

1,7-DAAC, 1,7-bis(alkylamino)diazachrysene; BoNT, botulinum neurotoxin; BoNT/A LC, botulinum neurotoxin serotype A light chain; 4,7-ACQ, 4-amino-7-chloroquinoline; $\mathrm{CQ}$ chloroquine; MFQ mefloquine; ART, artemisinin; MLM, HLM, mouse and human liver microsomes, respectively

\section{REFERENCES}

(1) Burnett, J. C.; Henchal, E. A.; Schmaljohn, A. L.; Bavari, S. The evolving field of biodefence: therapeutic developments and diagnostics. Nature Rev. Drug Discovery 2005, 4, 281-297.

(2) (a) Paddle, B. M. Therapy and prophylaxis of inhaled biological toxins. J. Appl. Toxicol. 2003, 23, 139-170. (b) Wein, L. M.; Liu, Y. Analyzing a bioterror attack on the food supply: the case of botulinum toxin in milk. Proc. Natl. Acad. Sci. U.S.A. 2005, 102, 9984-9989.

(3) Willis, B.; Eubanks, L. M.; Dickerson, T. J.; Janda, K. D. The strange case of the botulinum neurotoxin: using chemistry and biology to modulate the most deadly poison. Angew. Chem., Int. Ed. Engl. 2008, $47,8360-8379$.

(4) Emergency Preparedness and Response: Bioterrorism Agents/Diseases; http://emergency.cdc.gov/agent/agentlist-category.asp.

(5) (a) Singh, B. R. Intimate details of the most poisonous poison. Nature Struct. Biol. 2000, 7, 617-619. (b) Turton, K.; Chaddock, J. A.; Acharya, K. R. Botulinum and tetanus neurotoxins: structure, function and therapeutic utility. Trends Biochem. Sci. 2002, 27, 552-558.

(6) Arnon, S. S.; Schechter, R.; Inglesby, T. V.; Henderson, D. A.; Bartlett, J. G.; Ascher, M. S.; Eitzen, E.; Fine, A. D.; Hauer, J.; Layton, M.; Lillibridge, S.; Osterholm, M. T.; O’Toole, T.; Parker, G.; Perl, T. M.; Russell, P. K.; Swerdlow, D. L.; Tonat, K. Botulinum toxin as a biological weapon: medical and public health management. JAMA, J. Am. Med. Assoc. 2001, 285, 1059-1070.

(7) Cai, S.; Singh, B. R. Strategies to design inhibitors of Clostridium botulinum neurotoxins. Infect. Disord. Drug Targets 2007, 7, 47-57.

(8) Binz, T.; Blasi, J.; Yamasaki, S.; Baumeister, A.; Link, E.; Sudhof, T. C.; Jahn, R.; Niemann, H. Proteolysis of SNAP-25 by types E and A botulinal neurotoxins. J. Biol. Chem. 1994, 269, 1617-1620.

(9) (a) Foran, P. G.; Davletov, B.; Meunier, F. A. Getting muscles moving again after botulinum toxin: novel therapeutic challenges. Trends Mol. Med. 2003, 9, 291-299. (b) Foran, P. G.; Mohammed, N.; Lisk, G. O.; Nagwaney, S.; Lawrence, G. W.; Johnson, E.; Smith, L.; Aoki, K. R.; Dolly, J. O. Evaluation of the therapeutic usefulness of botulinum neurotoxin $\mathrm{B}, \mathrm{C} 1, \mathrm{E}$, and $\mathrm{F}$ compared with the long lasting type A. Basis for distinct durations of inhibition of exocytosis in central neurons. J. Biol. Chem. 2003, 278, 1363-1371.

(10) Wells, T. N.; Alonso, P. L.; Gutteridge, W. E. New medicines to improve control and contribute to the eradication of malaria. Nature Rev. Drug Discovery 2009, 8, 879-891.

(11) Malaria Foundation International; http://www.malaria.org/.

(12) (a) Andriantsoanirina, V.; Ratsimbasoa, A.; Bouchier, C.; Jahevitra, M.; Rabearimanana, S.; Radrianjafy, R.; Andrianaranjaka, V.; Randriantsoa, T.; Rason, M. A.; Tichit, M.; Rabarijaona, L. P.; MercereauPuijalon, O.; Durand, R.; Menard, D. Plasmodium falciparum drug resistance in Madagascar: facing the spread of unusual pfdhfr and pfmdr-1 haplotypes and the decrease of dihydroartemisinin susceptibility. Antimicrob. Agents Chemother. 2009, 53, 4588-4597. (b) Bonnet, M.; Broek, I.; van Herp, M.; Urrutia, P. P.; van Overmeir, C.; Kyomuhendo, J.; Ndosimao, C. N.; Ashley, E.; Guthmann, J. P. Varying efficacy of artesunate+amodiaquine and artesunate+sulphadoxine-pyrimethamine for the treatment of uncomplicated falciparum malaria in the Democratic Republic of Congo: a report of two in vivo studies. Malar. J. 2009, 8, 192. (c) Dondorp, A. M.; Yeung, S.; White, L.; Nguon, C.; Day, N. P.; Socheat, D.; von Seidlein, L. Artemisinin resistance: current status and scenarios for containment. Nature Rev. Microbiol. 2010, 8, 272-280.

(13) (a) Opsenica, I.; Opsenica, D.; Lanteri, C. A.; Anova, L.; Milhous, W. K.; Smith, K. S.; Šolaja, B. A. New chimeric antimalarials with 4-aminoquinoline moiety linked to a tetraoxane skeleton. J. Med. Chem. 2008, 51, 6216-6219. (b) Dong, Y.; Wittlin, S.; Sriraghavan, K.; Chollet, J.; Charman, S. A.; Charman, W. N.; Scheurer, C.; Urwyler, H.; Santo Tomas, J.; Snyder, C.; Creek, D. J.; Morizzi, J.; Koltun, M.; Matile, H.; Wang, X.; Padmanilayam, M.; Tang, Y.; Dorn, A.; Brun, R.; Vennerstrom, J. L. The structure-activity relationship of the antimalarial ozonide arterolane (OZ277). J. Med. Chem. 2010, 53, 481-491. (c) Cosledan, F.; Fraisse, L.; Pellet, A.; Guillou, F.; Mordmuller, B.; Kremsner, P. G.; Moreno, A.; Mazier, D.; Maffrand, J. P.; Meunier, B. Selection of a trioxaquine as an antimalarial drug candidate. Proc. Natl. Acad. Sci. U.S.A 2008, 105, 17579-17584. (d) Opsenica, D.; Šolaja, B. A. Antimalarial peroxides. J. Serb. Chem. Soc. 2009, 74, 1155-1193and references therein. (e) Barton, V.; Ward, S. A.; Chadwick, J.; Hill, A.; O'Neill, P. M. Rationale design of biotinylated antimalarial endoperoxide carbon centered radical prodrugs for applications in proteomics. J. Med. Chem. 2010, 53, 4555-4559. (f) Bellot, F.; Cosledan, F.; Vendier, L.; Brocard, J.; Meunier, B.; Robert, A. Trioxaferroquines as new hybrid antimalarial drugs. J. Med. Chem. 2010, 53, 4103-4109.

(14) (a) de Villiers, K. A.; Egan, T. J. Recent advances in the discovery of haem-targeting drugs for malaria and schistosomiasis. Molecules 2009, 14, 2868-2887. (b) Egan, T. J. Recent advances in understanding the mechanism of hemozoin (malaria pigment) formation. J. Inorg. Biochem. 2008, 102, 1288-1299.

(15) (a) Hastings, I. M.; Bray, P. G.; Ward, S. A. Parasitology. A requiem for chloroquine. Science 2002, 298, 74-75. (b) Henry, M.; Alibert, S.; Rogier, C.; Barbe, J.; Pradines, B. Inhibition of efflux of quinolines as new therapeutic strategy in malaria. Curr. Top. Med. Chem. 2008, 8, 563-578.

(16) Cabrera, M.; Paguio, M. F.; Xie, C.; Roepe, P. D. Reduced digestive vacuolar accumulation of chloroquine is not linked to resistance to chloroquine toxicity. Biochemistry 2009, 48, 11152-11154.

(17) Lanteri, C. A.; Johnson, J. D.; Waters, N. C. Recent advances in malaria drug discovery. Recent Pat. Anti-infect. Drug Discovery 2007, 2, 95-114.

(18) (a) Plouffe, D.; Brinker, A.; McNamara, C.; Henson, K.; Kato, N.; Kuhen, K.; Nagle, A.; Adrian, F.; Matzen, J. T.; Anderson, P.; Nam, T. G.; Gray, N. S.; Chatterjee, A.; Janes, J.; Yan, S. F.; Trager, R.; Caldwell, J. S.; Schultz, P. G.; Zhou, Y.; Winzeler, E. A. In silico activity profiling reveals the mechanism of action of antimalarials discovered in a high-throughput screen. Proc. Natl. Acad. Sci. U.S.A. 2008, 105, 90599064. (b) Wu, T.; Nagle, A.; Sakata, T.; Henson, K.; Borboa, R.; Chen, Z.; Kuhen, K.; Plouffe, D.; Winzeler, E.; Adrian, F.; Tuntland, T.; Chang, J.; Simerson, S.; Howard, S.; Ek, J.; Isbell, J.; Deng, X.; Gray, N. S.; Tully, D. C.; Chatterjee, A. K. Cell-based optimization of novel benzamides as potential antimalarial leads. Bioorg. Med. Chem. Lett. 
2009, 19, 6970-6974. (c) Milner, E.; McCalmont, W.; Bhonsle, J.; Caridha, D.; Carroll, D.; Gardner, S.; Gerena, L.; Gettayacamin, M.; Lanteri, C.; Luong, T.; Melendez, V.; Moon, J.; Roncal, N.; Sousa, J.; Tungtaeng, A.; Wipf, P.; Dow, G. Structure-activity relationships amongst 4-position quinoline methanol antimalarials that inhibit the growth of drug sensitive and resistant strains of Plasmodium falciparum. Bioorg. Med. Chem. Lett. 2010, 20, 1347-1351. (d) Milner, E.; McCalmont, W.; Bhonsle, J.; Caridha, D.; Cobar, J.; Gardner, S.; Gerena, L.; Goodine, D.; Lanteri, C.; Melendez, V.; Roncal, N.; Sousa, J.; Wipf, P.; Dow, G. S. Anti-malarial activity of a nonpiperidine library of nextgeneration quinoline methanols. Malar. J. 2010, 9 (51), 1-10.

(19) (a) Andrews, S.; Burgess, S. J.; Skaalrud, D.; Kelly, J. X.; Peyton, D. H. Reversal agent and linker variants of reversed chloroquines: activities against Plasmodium falciparum. J. Med. Chem. 2010, 53, 916919. (b) October, N.; Watermeyer, N. D.; Yardley, V.; Egan, T. J.; Ncokazi, K.; Chibale, K. Reversed chloroquines based on the 3,4dihydropyrimidin-2(1H)-one scaffold: synthesis and evaluation for antimalarial, beta-haematin inhibition, and cytotoxic activity. ChemMedChem 2008, 3, 1649-1653.

(20) Kelly, J. X.; Smilkstein, M. J.; Brun, R.; Wittlin, S.; Cooper, R. A.; Lane, K. D.; Janowsky, A.; Johnson, R. A.; Dodean, R. A.; Winter, R.; Hinrichs, D. J.; Riscoe, M. K. Discovery of dual function acridones as a new antimalarial chemotype. Nature 2009, 459, 270-273.

(21) Musonda, C. C.; Whitlock, G. A.; Witty, M. J.; Brun, R.; Kaiser, M. Chloroquine-astemizole hybrids with potent in vitro and in vivo antiplasmodial activity. Bioorg. Med. Chem. Lett. 2009, 19, 481-484.

(22) Gemma, S.; Campiani, G.; Butini, S.; Joshi, B. P.; Kukreja, G.; Coccone, S. S.; Bernetti, M.; Persico, M.; Nacci, V.; Fiorini, I.; Novellino, E.; Taramelli, D.; Basilico, N.; Parapini, S.; Yardley, V.; Croft, S.; KellerMaerki, S.; Rottmann, M.; Brun, R.; Coletta, M.; Marini, S.; Guiso, G.; Caccia, S.; Fattorusso, C. Combining 4-aminoquinoline- and clotrimazole-based pharmacophores toward innovative and potent hybrid antimalarials. J. Med. Chem. 2009, 52, 502-513.

(23) (a) Iwaniuk, D. P.; Whetmore, E. D.; Rosa, N.; Ekoue-Kovi, K.; Alumasa, J.; de Dios, A. C.; Roepe, P. D.; Wolf, C. Synthesis and antimalarial activity of new chloroquine analogues carrying a multifunctional linear side chain. Bioorg. Med. Chem. 2009, 17, 6560-6566. (b) Blackie, M. A.; Yardley, V.; Chibale, K. Synthesis and evaluation of phenylequine for antimalarial activity in vitro and in vivo. Bioorg. Med. Chem. Lett. 2010, 20, 1078-1080. (c) Guetzoyan, L.; Yu, X. M.; Ramiandrasoa, F.; Pethe, S.; Rogier, C.; Pradines, B.; Cresteil, T.; Perree-Fauvet, M.; Mahy, J. P. Antimalarial acridines: synthesis, in vitro activity against $P$. falciparum and interaction with hematin. Bioorg. Med. Chem. 2009, 17, 8032-8039.

(24) Bausch, D. G.; Towner, J. S.; Dowell, S. F.; Kaducu, F.; Lukwiya, M.; Sanchez, A.; Nichol, S. T.; Ksiazek, T. G.; Rollin, P. E. Assessment of the risk of Ebola virus transmission from bodily fluids and fomites. J. Infect. Dis. 2007, 196 (Suppl 2), S142-S147.

(25) Kuhn, J. H. Filoviruses. A compendium of 40 years of epidemiological, clinical, and laboratory studies. Arch. Virol. Suppl. 2008, 20, 13-360.

(26) Health Topics: Haemorrhagic Fevers, Viral; World Health Organization: Geneva; http://www.who.int/topics/haemorrhagic fevers viral/en/.

(27) (a) Aman, M. J.; Kinch, M. S.; Warfield, K.; Warren, T.; Yunus, A.; Enterlein, S.; Stavale, E.; Wang, P.; Chang, S.; Tang, Q.; Porter, K.; Goldblatt, M.; Bavari, S. Development of a broad-spectrum antiviral with activity against Ebola virus. Antiviral Res. 2009, 83, 245-251. (b) Gunther, S.; Asper, M.; Roser, C.; Luna, L. K.; Drosten, C.; Becker-Ziaja, B.; Borowski, P.; Chen, H. M.; Hosmane, R. S. Application of real-time PCR for testing antiviral compounds against Lassa virus, SARS coronavirus and Ebola virus in vitro. Antiviral Res. 2004, 63, 209215. (c) Warren, T. K.; Warfield, K. L.; Wells, J.; Enterlein, S.; Smith, M.; Ruthel, G.; Yunus, A. S.; Kinch, M. S.; Goldblatt, M.; Aman, M. J.; Bavari, S. Antiviral activity of a small-molecule inhibitor of filovirus infection. Antimicrob. Agents Chemother. 2010, 54, 2152-2159.

(28) Chong, C. R.; Sullivan, D. J., Jr. New uses for old drugs. Nature 2007, 448, 645-646.
(29) Sundar, S.; Jha, T. K.; Thakur, C. P.; Engel, J.; Sindermann, H.; Fischer, C.; Junge, K.; Bryceson, A.; Berman, J. Oral miltefosine for Indian visceral leishmaniasis. N. Engl. J. Med. 2002, 347, 1739-1746.

(30) Shen, Y.; Zhukovskaya, N L.; Zimmer, M. I.; Soelaiman, S.; Bergson, P.; Wang, C. R.; Gibbs, C. S.; Tang, W. J. Selective inhibition of anthrax edema factor by adefovir, a drug for chronic hepatitis B virus infection. Proc. Natl. Acad. Sci. U.S.A 2004, 101, 3242-3247.

(31) Burnett, J. C.; Schmidt, J. J.; Stafford, R. G.; Panchal, R. G.; Nguyen, T. L.; Hermone, A. R; Vennerstrom, J. L.; McGrath, C. F.; Lane, D. J.; Sausville, E. A.; Zaharevitz, D. W.; Gussio, R.; Bavari, S. Novel small molecule inhibitors of botulinum neurotoxin A metalloprotease activity. Biochem. Biophys. Res. Commun. 2003, 310, 84-93.

(32) Burnett, J. C.; Ruthel, G.; Stegmann, C. M.; Panchal, R. G.; Nguyen, T. L.; Hermone, A. R.; Stafford, R. G.; Lane, D. J.; Kenny, T. A.; McGrath, C. F.; Wipf, P.; Stahl, A. M.; Schmidt, J.J.; Gussio, R.; Brunger, A. T.; Bavari, S. Inhibition of metalloprotease botulinum serotype A from a pseudopeptide binding mode to a small molecule that is active in primary neurons. J. Biol. Chem. 2007, 282, 5004-5014.

(33) Burnett, J. C.; Opsenica, D.; Sriraghavan, K.; Panchal, R. G.; Ruthel, G.; Hermone, A. R.; Nguyen, T. L.; Kenny, T. A.; Lane, D. J.; McGrath, C. F.; Schmidt, J. J.; Vennerstrom, J. L.; Gussio, R.; Šolaja, B. A.; Bavari, S. A refined pharmacophore identifies potent 4-amino-7chloroquinoline-based inhibitors of the botulinum neurotoxin serotype A metalloprotease. J. Med. Chem. 2007, 50, 2127-2136.

(34) Šlaja, B. A.; Opsenica, D.; Smith, K. S.; Milhous, W. K.; Terzic, N.; Opsenica, I.; Burnett, J. C.; Nuss, J.; Gussio, R.; Bavari, S. Novel 4-aminoquinolines active against chloroquine-resistant and sensitive P. falciparum strains that also inhibit botulinum serotype A. J. Med. Chem. 2008, 51, 4388-4391.

(35) Hermone, A. R.; Burnett, J. C.; Nuss, J. E.; Tressler, L. E.; Nguyen, T. L.; Šolaja, B. A.; Vennerstrom, J. L.; Schmidt, J. J.; Wipf, P.; Bavari, S.; Gussio, R. Three-dimensional database mining identifies a unique chemotype that unites structurally diverse botulinum neurotoxin serotype A inhibitors in a three-zone pharmacophore. ChemMedChem 2008, 3, 1905-1912.

(36) (a) Schmidt, J. J.; Bostian, K. A. Endoproteinase activity of type A botulinum neurotoxin: substrate requirements and activation by serum albumin. J. Protein Chem. 1997, 16, 19-26. (b) Schmidt, J. J.; Bostian, K. A. Proteolysis of synthetic peptides by type A botulinum neurotoxin. J. Protein Chem. 1995, 14, 703-708. (c) Schmidt, J. J.; Stafford, R. G. Fluorigenic substrates for the protease activities of botulinum neurotoxins, serotypes A, B, and F. Appl. Environ. Microbiol. 2003, 69, 297-303. (d) Schmidt, J. J.; Stafford, R. G. A high-affinity competitive inhibitor of type A botulinum neurotoxin protease activity. FEBS Lett. 2002, 532, 423-426. (e) Schmidt, J. J.; Stafford, R. G.; Bostian, K. A. Type A botulinum neurotoxin proteolytic activity: development of competitive inhibitors and implications for substrate specificity at the $S 1^{\prime}$ binding subsite. FEBS Lett. 1998, 435, 61-64. (f) Schmidt, J. J.; Stafford, R. G.; Millard, C. B. High-throughput assays for botulinum neurotoxin proteolytic activity: serotypes A, B, D, and F. Anal. Biochem. 2001, 296, 130-137.

(37) Burnett, J. C.; Wang, C.; Nuss, J. E.; Nguyen, T. L.; Hermone, A. R.; Schmidt, J. J.; Gussio, R.; Wipf, P.; Bavari, S. Pharmacophoreguided lead optimization: the rational design of a non-zinc coordinating, submicromolar inhibitor of the botulinum neurotoxin serotype a metalloprotease. Bioorg. Med. Chem. Lett. 2009, 19, 5811-5813.

(38) Opsenica, D.; Pocsfalvi, G.; Juranic, Z.; Tinant, B.; Declercq, J. P.; Kyle, D. E.; Milhous, W. K.; Šolaja, B. A. Cholic acid derivatives as 1,2,4,5-tetraoxane carriers: structure and antimalarial and antiproliferative activity. J. Med. Chem. 2000, 43, 3274-3282.

(39) Parapini, S.; Basilico, N.; Pasini, E.; Egan, T. J.; Olliaro, P.; Taramelli, D.; Monti, D. Standardization of the physicochemical parameters to assess in vitro the beta-hematin inhibitory activity of antimalarial drugs. Exp. Parasitol. 2000, 96, 249-256.

(40) (a) Yamada, K.; Hakura, A.; Kato, T. A.; Mizutani, T.; Saeki, K. Nitrogen-substitution effects on the mutagenicity and cytochrome P450 isoform-selectivity of chrysene analogs. Mutat. Res. 2005, 586, 87-95.(b) Toxicological Profile For Polycyclic Aromatic Hydrocarbons. U.S. 
Department of Health and Human Services. Public Health Service Agency for Toxic Substances and Disease Registry: Atlanta, GA, 1995; http://www.atsdr.cdc.gov/toxprofiles/tp69.html.

(41) $\mathrm{IC}_{90}$ can be envisaged to represent a suitable compromise between the substantial amount of data obtainable with $\mathrm{IC}_{50}$ (value based on a relatively high number of parasites, but with less relevance to the therapeutic situation) and $\mathrm{IC}_{99}$ (reflects MIC and full efficacy, however, based on a relatively small number of surviving parasites available for analysis).

(42) Developmental Therapeutics Program; National Cancer Institute: Bethesda, $\mathrm{MD}$ (NCI); http://dtp.nci.nih.gov.

(43) Opsenica, I.; Terzic, N.; Opsenica, D.; Angelovski, G.; Lehnig, M.; Eilbracht, P.; Tinant, B.; Juranic, Z.; Smith, K. S.; Yang, Y. S.; Diaz, D. S.; Smith, P. L.; Milhous, W. K.; Dokovic, D.; Šlaja, B. A. Tetraoxane antimalarials and their reaction with $\mathrm{Fe}(\mathrm{II}) . J$. Med. Chem. 2006, 49, 3790-3799.

(44) Stable compounds were defined as having half-lives of $>60 \mathrm{~min}$.

(45) Desjardins, R. E.; Canfield, C. J.; Haynes, J. D.; Chulay, J. D. Quantitative assessment of antimalarial activity in vitro by a semiautomated microdilution technique. Antimicrob. Agents Chemother. 1979, 16, $710-718$.

(46) Milhous, W. K.; Weatherly, N. F.; Bowdre, J. H.; Desjardins, R. E. In vitro activities of and mechanisms of resistance to antifol antimalarial drugs. Antimicrob. Agents Chemother. 1985, 27, 525-30.

(47) Towner, J. S.; Paragas, J.; Dover, J. E.; Gupta, M.; Goldsmith, C. S.; Huggins, J. W.; Nichol, S. T. Generation of eGFP expressing recombinant Zaire ebolavirus for analysis of early pathogenesis events and high-throughput antiviral drug screening. Virology 2005, 332, 20-27.

(48) Moe, J. B.; Lambert, R. D.; Lupton, H. W. Plaque assay for Ebola virus. J. Clin. Microbiol. 1981, 13, 791-793.

(49) Panchal, R. G.; Kota, K. P.; Spurgers, K. B.; Ruthel, G.; Tran, J. P.; Boltz, R. C.; Bavari, S. Development of High-Content Imaging Assays for Lethal Viral Pathogens. J. Biomol. Screen. 2010, 15, 755-765.

(50) Gettayacamin, M.; Sattabongkot, J.; Hansukjariya, P.; Tungtaeng, A.; Kyle, D. Development of Anopheles dirus Sporozoite-Induced Mouse Malaria Model. Am. J. Trop. Med. Hyg. 2006, 75 (5S), 156-157.

(51) Chen, B. J.; Lamb, R. A. Mechanisms for enveloped virus budding: Can some viruses do without ESCRT?. Virology 2008, 371, 221-232.

(52) Dow, G. S.; Caridha, D.; Yourick, D.; Cabezas, M.; Wolf, L.; Hudson, T. H. Mefloquine-induced disruption of calcium homeostasis in mammalian cells is similar to that induced by ionomycin. Antimicrob. Agents Chemother. 2008, 52, 684-693. 